\title{
Thermal performance of a solar assisted horizontal ground heat exchanger
}

\author{
Yasameen Al-Ameen ${ }^{*, a}$, Anton Ianakiev ${ }^{a}$, Robert Evans ${ }^{\text {a }}$ \\ a School of Architecture, Design and the Built Environment, Nottingham Trent University, Nottingham, UK
}

\begin{abstract}
This paper presents an experimental study of a solar assisted horizontal ground heat exchanger system (HGHEs) operating as a daily heat storage unit. Initially, several soils were assessed as sensible heat storage mediums, with sand and gravel selected as the most appropriate. Then, a HGHEs was designed and connected to a $15 \mathrm{~m}^{2}$ test room with a heating load of $1 \mathrm{~kW}$ at Nottingham Trent University. Heating cables, simulating solar input, were used to heat the soil in the HGHEs to $70^{\circ} \mathrm{C}$, then a heat transfer fluid (HTF), was circulated through a closed loop heat exchanger to extract the stored heat. The parameters of soil backfill and HTF mass flow rate were investigated in the HGHEs. Several output flowrates ranging between 0.1 to $0.6 \mathrm{~L} / \mathrm{min}$ were tested, producing discharge times varying between a few hours to a few days. The HTF mass flowrate was found to be the most significant parameter, affecting the HGHEs thermal capacity and heat exchange rates. The sand filled HGHE produced approximately $50 \%$ more hot water $\left(\mathrm{T}>35^{\circ} \mathrm{C}\right)$ during a longer duration achieving an efficiency of $78 \%$ compared to the gravel filled HGHE with a lower system efficiency of 58\%. Insulating the HGHE system was found to reduce heat losses and avoid temperature fluctuations in the HGHEs. Overall, the results show the hot water quantity, temperature range and duration produced from the system were in line with low temperature district heating guidelines and can be applied to some household heating applications incorporating low flows and low temperatures.
\end{abstract}

Keywords: (Energy storage, Horizontal ground heat exchanger, Soils, Building, Space Heating)

\section{Introduction}

\subsection{Background}

Over recent years, there has been a shift from conventional resources towards energy efficient renewable sources of energy for building heating purposes (İnall \& Esen 2004). The use of solar energy is of considerable interest because it leads to diminution of fossil fuels consumption and is a non-polluting source of energy (Badescu 2002). Several types of solar energy systems are integrated with heat collection storage systems and have been developed for heating/cooling purposes in residential and commercial buildings. The main heat storage media are water, latent heat materials and ground materials. The ground is a stable heat exchange medium and is essentially unlimited and always available (Ozgener \& Hepbasli 2007; İnallı \& Esen 2004). Ground heat exchanger systems (GHEs) have gained recognition for improved and easy exploitation of thermal energy from the ground (Esen \& Yuksel 2013). Claims made by Garg (1985) are that GHEs can 1) collect heat more efficiently, 2) store more heat at a lower cost, 3) be cheaper to build, and 4) deliver a higher solar fraction with the same collector area compared to a water tank HGHE system maintaining a higher level of performance even in colder climates (Garg 1985; Ozgener \& Hepbasli 2007).

*Corresponding author: Yasameen.alameen@ntu.ac.uk 
GHEs installed for heating and cooling purposes in buildings have been extensively studied by various authors (Florides \& Kalogirou 2007; Luo et al. 2016). Closed ground-loop GHEs can either be installed in vertical (VGHEs) or horizontal (HGHEs) arrangement, and a comparison of HGHEs and VGHEs performance was studied by Lee et al. (2015). In this study, the focus was a solar assisted HGHEs with operating temperatures ranging between 35$70^{\circ} \mathrm{C}$ (Wong \& Snijders 2006). HGHEs consists of heat exchange pipes, the pipes can come in a variety of configurations including straight, coil, slinky or loops that are buried in shallow ground trenches of up to $1-2 \mathrm{~m}$ depths. A HTF (water or anti-freeze solution) is circulated through the system to extract the stored heat upon requirement and return the cooled HTF to the ground storage where it gathers further energy, in a continuous cycle. HGHEs are surrounded by soil, and hence the performance of the system is highly dependent on ground heat-transfer characteristics (Ball et al. 1983). Ground thermophysical properties including soil texture, grain size distribution, bulk density, water content and thermal conductivity are correlated and highly influences the heat transfer between the circulating HTF in the GHEs and the surrounding soil, affecting the performance of the system (Bertermann et al. 2015; Luo et al. 2016; Kim et al. 2016; Kavanaugh 2000). HGHEs are preferred over VGHEs for residential installations because of their lower initial installation costs (Naylor et al. 2015). Although HGHEs offer a costeffective and environmentally friendly alternative compared to other methods, large shallow land areas are required for pipe installations and the system is affected by temperature fluctuations caused by the system's proximity to the ground surface. Most GHEs are equipped with a ground source heat pump (GSHP) to assist the store charge and discharge process and to avoid the extreme high or low temperature conditions that compromise the energy performance of the systems (Wu 2010). Sarbu \& Sebarchievici (2015), provided a detailed literature regarding of GSHP systems, and their recent advances. Lund et al. (2005) reported that GSHPs have the largest energy use and installed capacity, according to 2005 data, accounting for $54.4 \%$ and $32.0 \%$ of the worldwide capacity and use.

Various experimental, numerical, economic and performance prediction studies related to GHEs have been reported in literature. The studies can be categorised into three broad groups: (i) Solar collectors coupled with a GSHP system (Yamankaradeniz \& Horuz 1998; Huang \& Chyng 2001; Kaygusuz 2000; Reyes et al. 1998; Ball et al. 1983); (ii) Ground heat exchanger systems coupled with a GSHP (Gan et al. 2007; Kim et al. 2016; Luo et al. 2016; Bertermann et al. 2015; İnallı \& Esen 2004; Esen et al. 2016; Esen et al. 2015; Cui et al. 2008; Florides \& Kalogirou 2007; Naylor et al. 2015; Wu et al. 2010; Ball et al. 1983) (iii) Solar collectors coupled with a GHEs and a GSHP for heating purposes (İnallı \& Esen 2004; Ozgener \& Hepbasli 2005a; Ozgener \& Hepbasli 2005b; Inalli \& Esen 2005; Verma \& Murugesan 2014; Badescu 2002; Esen et al. 2016). Bose \& Smith (1992) developed the first solar GHE, coupled with a GSHP at Oklahoma State University. GHEs coupled with a flat plate collector and GSHP were further developed by Ozgener et al. (2007), Yong \& Sumathy (2004) and Kupiec et al. (2015).

Extensive research has been undertaken into HGHEs by various researchers throughout the years, most of which were focused on monitoring HGHEs coupled with a GSHP where the heat pump output and the coefficient of performance (CoP) ratio was calculated to maintain daily indoor temperature. Other studies attempt to enhance the thermal performance of experimental HGHEs by improving the heat transfer between the surrounding soil and the heat exchanging pipes. The methods used to achieve this is by varying the heat exchange pipe properties, type and orientation. Esen \& Yuksel (2013) experimentally investigated greenhouse heating by biogas, solar and ground energy in Turkey's climate conditions and concluded that the slinky-type HGHEs occupies less space in the ground and can be successfully used for greenhouse heating purposes. Kim et al. (2016) investigated the performance of HGHE via experiments and numerical analyses in a steel box filled with dried Joomunjin sand, comparing coil-type and slinky-type heat exchange pipes performance in HGHEs and found slinky-type to have better performance. Gonzalez et al. (2012) conducted a study on the interactions between the soil, HGHE and the above ground environment in the UK and the results show that the slinky influences the surrounding soil by significantly decreasing soil temperatures. Koyun et al. (2009) studied the effects of burying aluminum finned pipes in the soil over the traditional plastic polypropylene (PPRC) pipe and concluded that aluminum finned pipe has higher heat transfer values and is therefore more useful in GHEs. İnallı \& Esen (2004) carried out experimental measurements of a HGHEs connected to a GSHP to validate the effects of the parameters including the buried depth of soil, the coupled heat exchanger, mass flow rate of the water-antifreeze solution and sewer water on the performance of the system to be used for space heating applications. Results show the CoP of the HGHEs in the different trenches, at 1 and 2 m depths, were different. Wu et al. (2010, 2011) experimentally and numerically studied the thermal 
performance of a HGHEs ground-coupled GSHP in a UK climate and concluded that heat extraction from the HGHEs increased with ambient temperature and soil thermal conductivity, however it decreased with increasing refrigerant temperature. Kim et al. (2016) also found that GHEs type and soil thermal conductivity are the main factors determining the heat exchange rate of a GHE, whereas the pipe diameter did not have any effect on the GHE performance. Congedo et al. (2012) carried out computer simulations on several HGHEs configurations considering soil thermal conductivity, installation depth, fluid velocity and concluded that the optimal soil type to use around the heat exchanging pipes was that with the highest thermal conductivity. Also, the HGHEs installation depth did not play an important role on the system performance.

\subsection{Study Objectives}

As evident from Section 1.1, a considerable amount of recent research has been devoted to pipe design characteristics and the addition of GSHP to HGHEs, with much less focus on the ground media used for storage and the air temperature fluctuations caused by the proximity of HGHEs to the ground surface. Moreover, there are limited studies in literature concerning improving the performance of solar PV panels and solar heat collectors assisted HGHEs. Therefore, the objectives of this study are twofold:

- The first objective was to present a comparative study of heat transfer in seven ground media.

- The second objective, was to investigate how excess electricity produced from solar PV panels can be more efficiently stored in an insulated HGHEs to heat a $15 \mathrm{~m}^{2}$ test room with a heating load of $1 \mathrm{~kW}$ during the typical winter conditions in Nottingham, UK (Temperature of $-6^{\circ} \mathrm{C}$ ) without the use of a GSHP. For this purpose, an experimental HGHEs was set-up using two soil types as backfill media including sand (LB) and gravel (GR) and tested under various HTF mass flow rates to evaluate the performance of the system in heating mode (charging) and extracting mode (discharging).

The novelty points of this study are: (1) The system simulates storing excess electricity generated from solar PV panels in the form of heat and/or storing heat obtained directly from a solar heat collectors, (2) Testing and comparing two soil backfill media in a HGHEs under the same working conditions including: the same solar radiation, ambient air temperature, collector materials, insulating materials and HGHE dimensions, (3) The HGHEs is insulated to avoid heat loss to the surroundings and reduce air temperature fluctuations caused by the proximity of HGHEs to the ground surface, and (4) The HGHEs does not use a GSHP to assist in the heating process. These points will assist designers in designing HGHEs.

\section{Experimental work}

The experimental work was divided into four activities as follows:

- Establishing soil thermophysical properties (Activity 2.1)

- Conducting thermal testing of soils (Activity 2.2)

- The experimental HGHE system set-up (Activity 2.3)

- The soil backfilled HGHE (Activity 2.4)

Seven soils were utilised in this experimental study, these include: Gravel (GR), Leighton buzzard sand (LB), Washed sand (WS), Building sand (BS), Mercia mudstone clay (MM), Gault clay (GA) and Lias clay (LI) as shown in Figure 1. From a designer's point of elevation, the selected soils represent different widely available and abundant soil types in the United Kingdom which are cheap, sustainable and can be purchased from local building merchants.

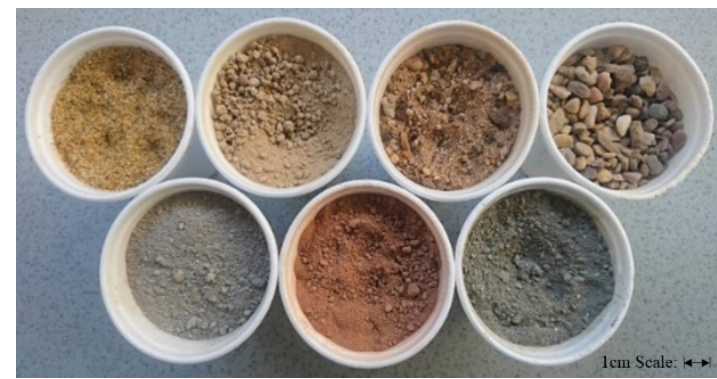

Figure 1: Soil materials, Top row left to right: LB, BS, WS, GR; Bottom row left to right: LI, MM, G 


\subsection{Establishing soil thermophysical properties}

The soils used in this study have fundamental thermophysical properties that determine their energy performance. These thermophysical properties include bulk and particle densities $\left(\rho_{b} \& \rho_{p}\right)$, porosity $(n)$, thermal conductivity $(K)$ and thermal resistivity $\left(R_{\lambda}\right)$ and are summarised in Table 1. Figure 2 shows the particle size distribution (PSD) curves for each of the tested soils. Soil properties were established using relevant British Standard testing procedures, these are contained within: BS 5930:1981 and BS 1377 for density and particle distribution tests, BS 7591-2:1992 for porosity and BS EN 12667:2001 for thermal testing.

Table 1

Thermophysical properties of selected soils utilized in this study

\begin{tabular}{lccccccc}
\hline Soil material \& abbreviation & $\begin{array}{c}\text { Particle } \\
\text { Size } \\
(\mathrm{mm})\end{array}$ & $\begin{array}{c}\text { Gradation } \\
\text { Classification }\end{array}$ & $\begin{array}{c}\boldsymbol{\rho}_{\boldsymbol{b}} \\
\left(\mathrm{kg} / \mathrm{m}^{3}\right)\end{array}$ & $\begin{array}{c}\boldsymbol{\rho}_{\boldsymbol{p}} \\
\left(\mathrm{kg} / \mathrm{m}^{3}\right)\end{array}$ & $\begin{array}{c}\boldsymbol{n} \\
(\%)\end{array}$ & $\begin{array}{c}\boldsymbol{K} \\
(\mathrm{W} / \mathrm{mK})\end{array}$ & $\begin{array}{c}\boldsymbol{R}_{\boldsymbol{\lambda}} \\
\left(\mathrm{m}^{\circ} \mathrm{C} / \mathrm{W}\right)\end{array}$ \\
\hline Gravel (GR) & $2-10$ & Uniform & 1451 & 2464 & 41.12 & 0.7 & 1.43 \\
Leighton Buzzard Sand (LB) & $0.6-1.18$ & Uniform & 1562 & 2620 & 40.40 & 0.26 & 3.89 \\
Washed Sand (WS) & $0.063-5$ & Uniform & 1719 & 2427 & 29.15 & 0.19 & 5.05 \\
Building Sand (BS) & $0.15-5$ & Uniform & 1401 & 1666 & 15.86 & 0.14 & 6.85 \\
Mercia Mudstone Clay (MM) & $0-2$ & Well & 1328 & 1475 & 10 & 0.12 & 8.53 \\
Gault Clay (GA) & $0-5$ & Well & 1210 & 1299 & 6.86 & 0.10 & 9.90 \\
Lias Clay (LI) & $0-5$ & Well & 1256 & 1326 & 5.27 & 0.13 & 7.45 \\
\hline
\end{tabular}

Note: Soils were dried overnight before testing, hence the moisture content for each soil is zero

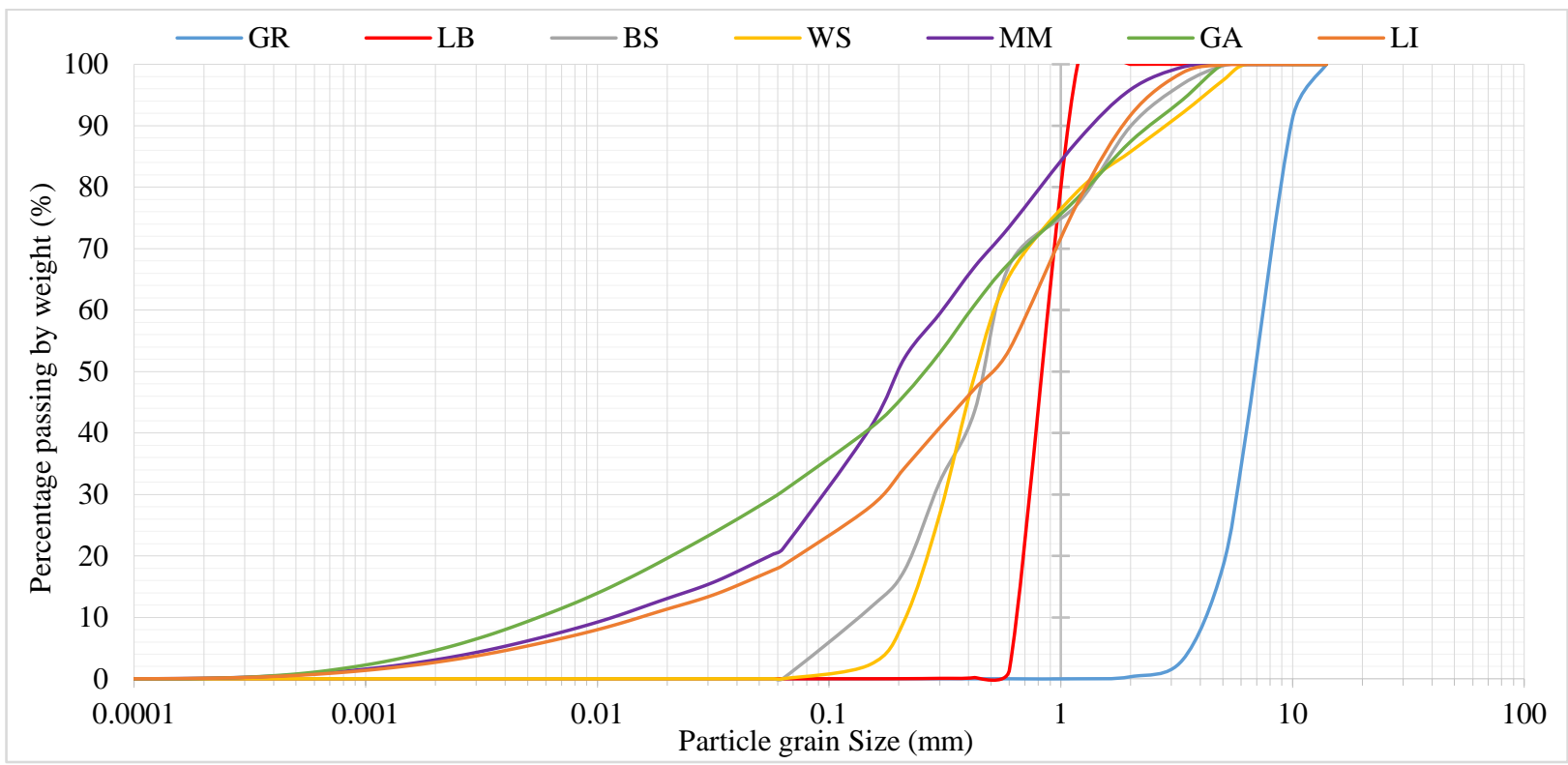

Figure 2: Particle size distribution chart for GR, LB, BS, WS, MM, GA and LI soil gradations

\subsection{Thermal testing of soils}

Each of the soils were tested in 10 litre containers (approximately weighing 15kg each, depending on soil density) to establish heating and cooling patterns. Seven containers were filled to the 10 litre mark with each of the seven soil and placed in an environmental chamber (Model: BRI I/06 Fisons series No 5257) and set to $70^{\circ} \mathrm{C}$. RS Pro Ktype thermocouples (chromel-alumel) attached to a central data logger were used to monitor temperature. Temperature readings were recorded at 5 minute intervals internally for the environmental chamber $\left(T_{E C}\right)$, externally for the room temperature $\left(T_{\text {room }}\right)$ and at five locations in the containers $\left(T_{\text {Left }}, T_{\text {Midd }}, T_{\text {Right }}, T_{\text {up }}, T_{\text {down }}\right)$ as illustrated in Figure 3 . After the soil filled containers reached a steady temperature of $70 \pm 2^{\circ} \mathrm{C}$, the containers were removed from the chamber and left to cool to ambient room temperature $\left(\approx 20^{\circ} \mathrm{C}\right)$. The tests were conducted side by side with a control LB sand filled container and repeated three times to assess comparability. 


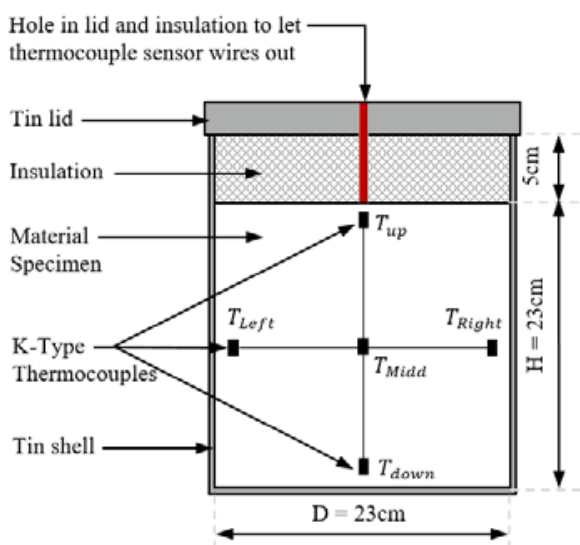

(a)

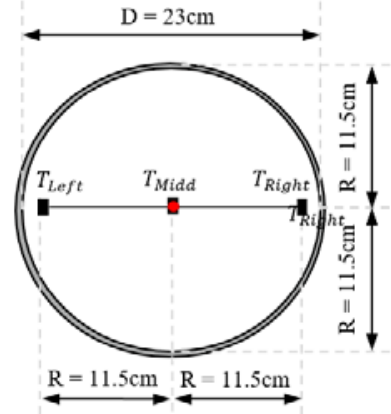

(b)

Figure 3: Cross sectional schematic diagram of the 10L containers used for testing (Dimensions in $\mathrm{cm}$ )

(a) Side elevation, (b) Top elevation

\subsection{Experimental HGHE system set-up}

An experimental HGHEs was designed and constructed in the soil laboratory facilities at Nottingham Trent University to investigate and evaluate the thermal performance of the system in heating mode (charging) and extracting mode (discharging). A detailed schematic diagram of the main components used in the system is shown in Figure 4. This set-up was designed for a $1 \mathrm{~kW}$ (test room heating load) at design conditions as calculated in section 4.1. The system consists of 25 individual components with the biggest component being the soil backfilled HGHE storage itself (component 10 on Figure 4). The system has two operation circuits running through it for (a) Heating [charging] HGHE (Red network on Figure 4) and (b) Extracting heat [discharging] from HGHE (Black network on Figure 4). These will be further described in the operation mode section.

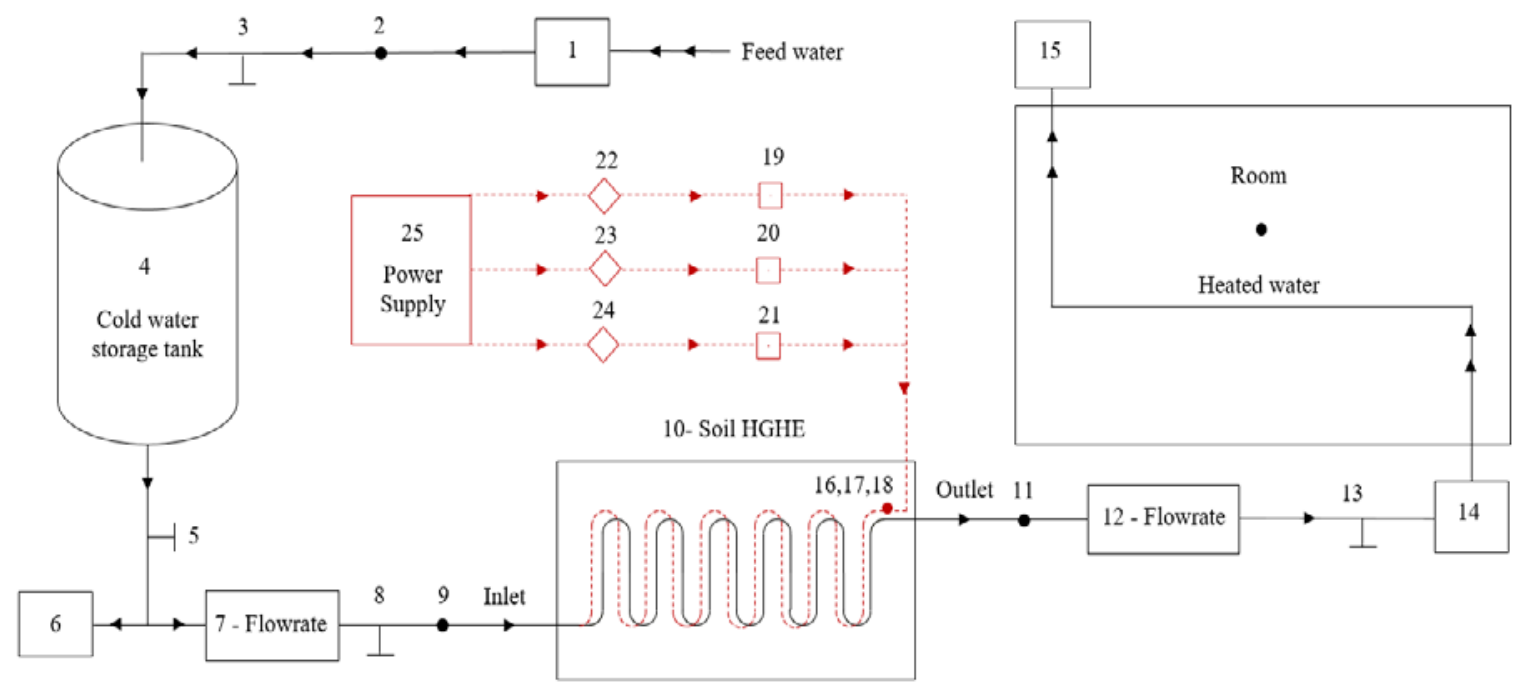

Figure.4: Schematic diagram of the heating system (see additional notes below)

Figure 4 notes: Network A (Red): Heating mode, Network B (Black): Extracting heat mode.

1: Cold water supply, 2: Sensor measures temperature of cold water, 3,5,8,13: Gate valves to control flow of water, 4: Water HGHE tank (capacity 50L), 6: Tank collection drain, 7,12: Water meters to monitor inlet and outlet flowrate, 9: Sensor measures water inlet temperature of HGHE, 10: Soil HGHE (see Figure 5,6,7 \& 8 for further details), 11: Sensor measures water outlet temperature of HGHE, 14: Tap control to alter flowrate of water, 15: Hot water collection drain, 16,17,18: Sensors measures heating cable temperature, 19,20,21: Digitally regulated thermostats to control temperature of heating cables on each of three layers, 22,23,24: Data logger attached to sensors detecting temperature and on/off thermostats timings to monitor the power used in the system, 25: Power supply to heating cable, sensors and digital thermostats. 


\subsection{Experimental HGHE}

Figure. 5 shows a 3D schematic of the soil backfilled HGHE storage used in this study along with material details. Further cross section elevation details are shown in Figure. 6 (plan), Figure. 7 (long) \& Figure. 8 (short). The inner dimensions of the HGHE storage are $0.5 \mathrm{~m}$ wide, $1 \mathrm{~m}$ long and $0.5 \mathrm{~m}$ high, allowing a soil capacity of approximately $450 \mathrm{~kg}$. The outer dimensions of the HGHE are larger to accommodate for insulation and provide material containment. A $50 \mathrm{~mm}$ thick extruded polystyrene foam (XEPS) with a low thermal conductivity of $0.033 \mathrm{~W} / \mathrm{mK}$ was used to insulate the HGHE and avoid heat losses to the surroundings during testing. The thermophysical properties of the materials utilised within the HGHE are summarised in Table 2.

Table 2

Thermophysical properties of materials utilized within HGHE storage

\begin{tabular}{lccccc}
\hline \multicolumn{1}{c}{ HGHE Region } & Thickness & Material & $\begin{array}{c}\boldsymbol{\rho} \\
\left(\mathrm{kg} / \mathrm{m}^{3}\right)\end{array}$ & $\begin{array}{c}K \\
(\mathrm{w} / \mathrm{mK})\end{array}$ & $\begin{array}{c}\boldsymbol{C}_{\boldsymbol{p}} \\
(\mathrm{J} / \mathrm{kg} \mathrm{K})\end{array}$ \\
\hline Cover & $25 \mathrm{~mm}$ & Wood (MDF) & 700 & 0.15 & 1700 \\
Insulation & $50 \mathrm{~mm}$ & Polystyrene (XEPS) & 33 & 0.033 & 1131 \\
Pipe - Network B & $\emptyset_{\text {ext }}=10 \mathrm{~mm} \mathrm{\&} \emptyset_{\text {int }}=7 \mathrm{~mm}$ & Copper & 8950 & 401 & 385 \\
HTF - Network B & NA & Water liquid & 1000 & 0.6 & 4200 \\
External environment & NA & Air & 1.225 & 0.0242 & 1006.43 \\
\hline
\end{tabular}

Where: NA = Not applicable

HTF $=$ Heat transfer fluid

MDF $=$ Modified density fibreboard

XEPS $=$ Extruded expanded polystyrene

$\emptyset_{\text {ext }}=$ external copper pipe diameter

$\emptyset_{\text {int }}=$ internal copper pipe diameter

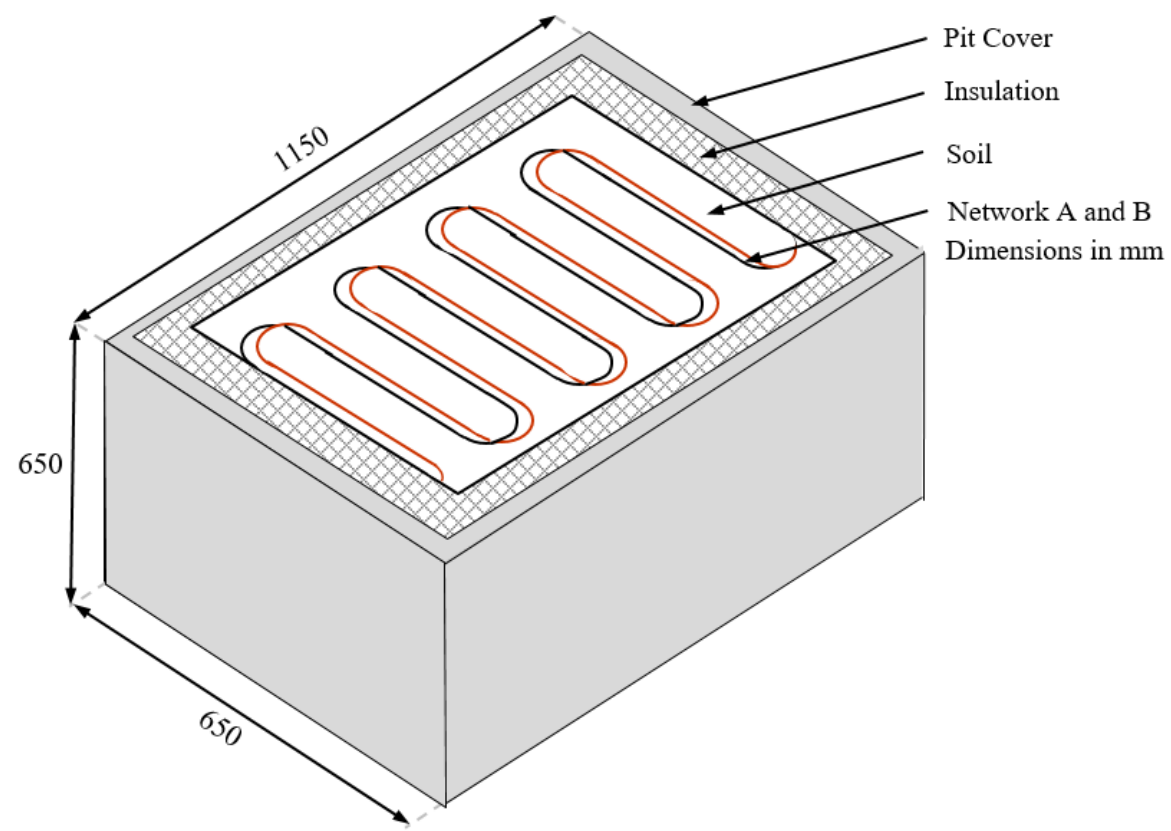

Figure. 5: 3D schematic diagram of the soil backfilled HGHE storage (Dimensions in mm)

\subsubsection{Operation modes:}

The HGHEs in this study was designed as a daily heat storage unit. During the day, when there is plenty of sunlight, the excess electricity from PV and/or the excess heat collected from solar thermal collectors can be stored in the HGHEs to be later used at night (when heat is required). The HGHE system operates using two networks. Network A is used for heating the storage [HGHE charging] (Red network on Figure's 4,5,6,7 \& 8) and Network B is used for extracting the stored heat from the storage [HGHE discharging] (Black network on Figure's 4,5,6,7 \& 8). The networks are described below. 


\section{Network A: HGHE Charging}

The soil in the HGHE was heated (charging mode) using electric heating cables (Network A). The cables were $10 \mathrm{~mm}$ in diameter and follow the pattern shown in Figure. 6 (plan elevation), running on three layers and spaced at $125 \mathrm{~mm}$ centers as shown in Figure. $7 \& 8$ (side elevation). The cables were temperature regulated using thermostats to reach temperatures of $65^{\circ} \mathrm{C} \pm 5^{\circ} \mathrm{C}$ simulating temperatures achieved from either solar thermal collectors and/or excess generated electricity produced from solar PV panels (240W). Once the HGHE reached a homogenous temperature of $65^{\circ} \mathrm{C} \pm 5^{\circ} \mathrm{C}$, the heating cables were switched off and the heat was extracted using Network B.

\section{Network B: HGHE Discharging}

A 10mm diameter copper pipe buried in the soil was used to extract the heat from the HGHE (Network B). The pipe was $15 \mathrm{~m}$ long (continuous) and ran on three layers in the HGHE at $125 \mathrm{~mm}$ centres. Copper piping was used due to its suitability for HGHEs as described by Yang (2013). The heat extraction from the HGHE to the heating load is maintained using water as a HTF, which circulates through the pipe work from a water storage tank unit (component 4 on Figure. 4). New fresh water $\left(\approx 18^{\circ} \mathrm{C}\right)$ was used for the start of each test. Water was used due to its low cost, wide availability, and desirable thermal properties. Swardt \& Meyer (2001) states that the utilization of water reticulation systems as a heat source/sink is a viable method of optimizing energy usage. Network B runs identically above Network A and follows the path illustrated in Figure. 6 (plan elevation). As illustrated in Figure. 7, the HTF runs through the heated HGHE from the inlet at the top to the outlet at the bottom and is continually heated by the heat exchange occurring between the heated soil and colder fluid in the pipe until the soil loses the stored heat and reaches equilibrium temperature with the input water temperature. In order to increase the heat transfer area between the copper pipe to the surrounding soil, the pipework was formed in a U-bended repeat pattern as illustrated in Figure. 6.

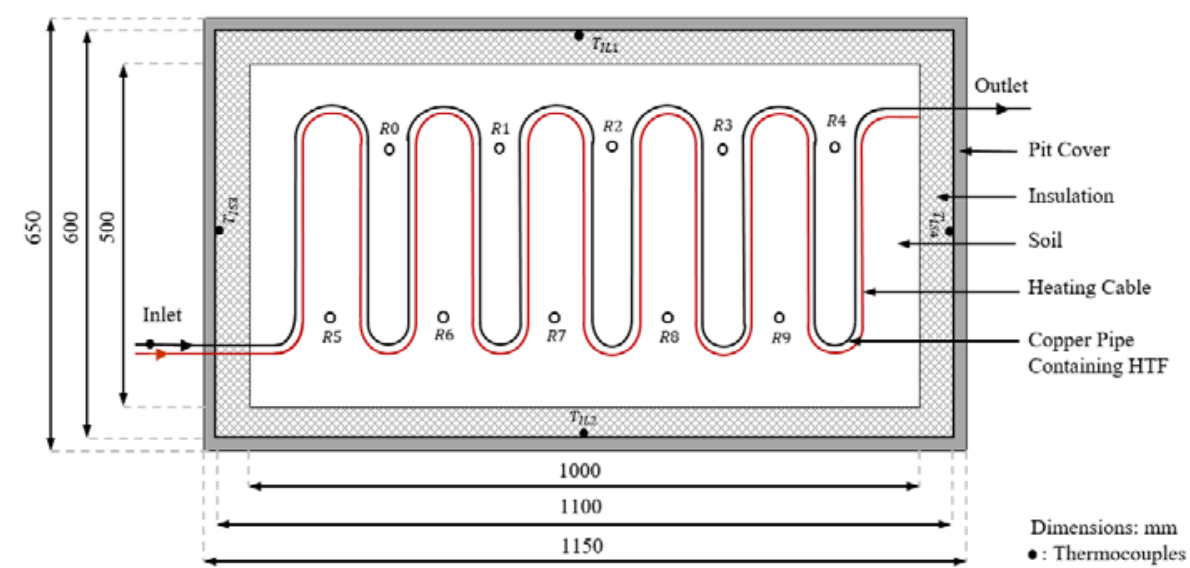

Figure. 6: Schematic diagram of plan elevation of soil filled HGHE (Dimensions in mm)

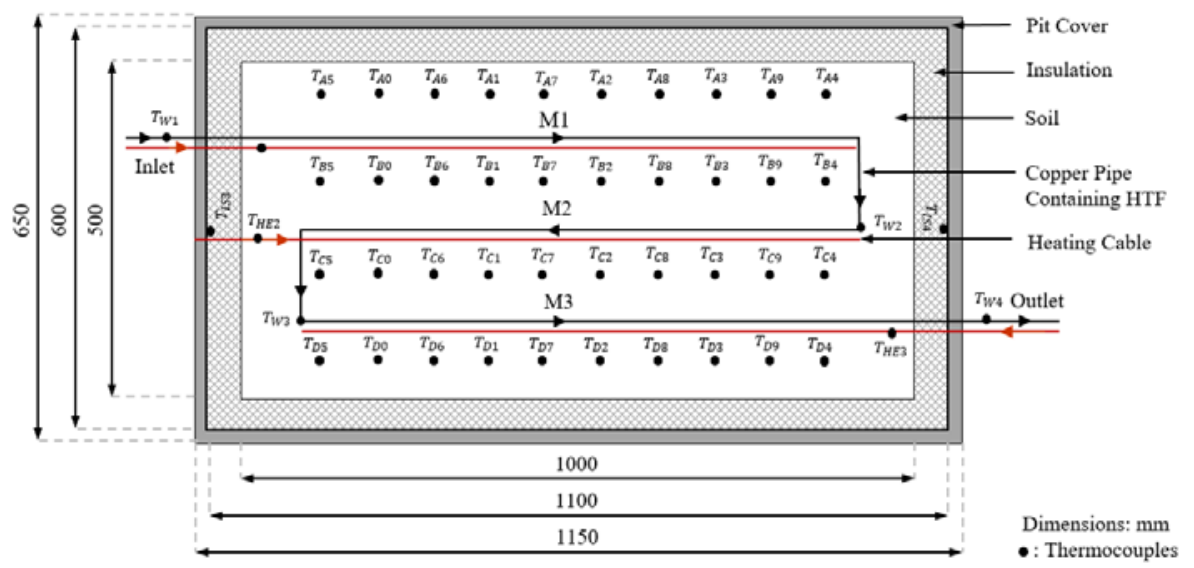

Figure. 7: Schematic diagram of long side elevation of soil filled HGHE (Dimensions in mm) 


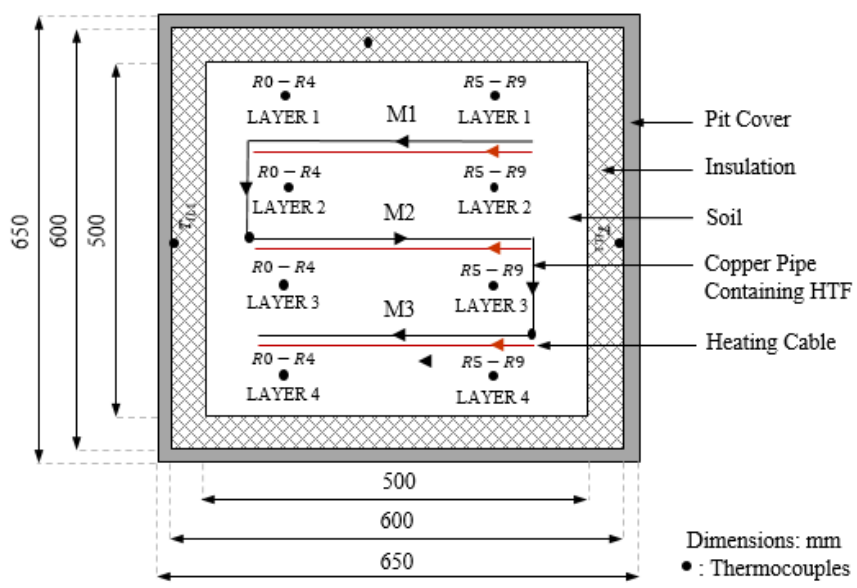

Figure. 8: Schematic diagram of short side elevations of soil filled HGHE (Dimensions in mm)

\subsubsection{Measurements}

Tests were conducted on the HGHEs between August 2016 to March 2017. The following measured data were recorded from the HGHEs at 5-minute time intervals under steady-state flow conditions;

(a) Temperature of HTF entering and leaving the HGHE by thermocouples.

(b) Temperature of HTF inside the HGHE by thermocouples.

(c) Temperature of experimental room by thermocouples.

(d) Temperature of outer insulation by thermocouples.

(e) Temperature of soil within HGHE (Layers 1,2,3 and 4 - See Figure's 7 \& 8) by thermocouples.

(f) Mass flow rate of HTF by a flowmeter.

(g) Electric power input to heating cables and thermostats by a wattmeter.

Figure's 6, 7 and 8 illustrates the layout of 50 K-type (chromel-alumel) thermocouples embedded within the HGHE. Temperatures were recorded with a regular time step of 5 minutes during storage charging and discharging using a datawel acquisition computer based data logger allowing time-temperature relationships to be analyzed. 40 of these thermocouples were distributed in the HGHE storage using ten systematically placed threaded rods (Rods R0-R9) to measure the buried soil's temperature as illustrated in Figure 6. Temperature was also recorded at four levels within the HGHE at Layers 1 (437.5mm FB), Layer 2 (312.5mm FB), Layer 3 (187.5mm FB) and Layer 4 (62.5mm FB) (See Figure 8). The ten temperature readings on each layer were averaged to derive an overall time-temperature relationship.

To monitor the circulating HTF temperature, four thermocouples were embedded into the copper pipe, this enabled the temperature of the running HTF to be monitored at the store inlet ( $\left.\mathrm{T}_{\mathrm{w} 1}\right)$, start of M2 ( $\left.\mathrm{T}_{\mathrm{w} 2}\right)$, start of M3 ( $\left.\mathrm{T}_{\mathrm{w} 3}\right)$ and at the store outlet $\left(\mathrm{T}_{\mathrm{w} 4}\right)$ as illustrated in Figure 7. A further four thermocouples were sandwiched between the MDF storage cover and insulation layer to assess heat losses from the HGHE. These four sensors were placed in the middle of the 2 long faces $\left(\mathrm{T}_{\mathrm{IL} 1}, \mathrm{~T}_{\mathrm{IL} 2}\right.$ ) and 2 short faces $\left(\mathrm{T}_{\mathrm{IS} 3}, \mathrm{~T}_{\mathrm{IS} 4}\right.$ ) as illustrated in Figure 6. The ambient air temperature $\left(\mathrm{T}_{\text {room }}\right.$ ) was also monitored for completeness of data, the $\mathrm{T}_{\text {room }}$ sensor was kept sheltered to protect the it from direct sunlight.

The HGHEs relied on gravity for HTF circulation from the overhead water storage tank with a head difference of $3 \mathrm{~m}$. The maximum HTF output flowrate was $0.7 \mathrm{~L} / \mathrm{min}$ and could be adjusted down to a minimum of $0.1 \mathrm{~L} / \mathrm{min}$. The flow rate of the circulated HTF through the closed loop system was measured using a flowmeter and controlled by a manual valve mounted to the HGHE. Gate valves were also installed in the system as illustrated in Figure 5 (components 3,5,8,13) allowing the system to be drained at different locations if required. The time-temperature relationships could subsequently relate to flow-rate of the HTF. 


\section{Uncertainty analysis}

An uncertainty analysis has been conducted in this study utilizing the Holman (1994) accepted method stated in the experimental methods for engineers book. Esen et al. (2006) who conducted similar research into GHEs also used this method in determining the uncertainty of data. Holman (1994) states the result ' $R$ ' is a given function of the measured independent variables $\mathrm{w}_{1}, \mathrm{w}_{2}, \ldots, \mathrm{w}_{\mathrm{n}}$ considered during testing. If the uncertainties in the independent variables all have the same odds, then the uncertainty $\mathrm{w}_{\mathrm{R}}$ in result having these odds is calculated using equation 1. In this study, temperatures, mass flow rates, voltages and amperes were measured with appropriate instruments explained previously. The total uncertainties of the measured parameters are presented in Table 3.

$w_{R}=\left[\left(\frac{\partial R}{\partial x_{1}} w_{1}\right)^{2}+\left(\frac{\partial R}{\partial x_{2}} w_{2}\right)^{2}+\cdots+\left(\frac{\partial R}{\partial x_{n}} w_{n}\right)^{2}\right]^{1 / 2}$

Where, $\mathrm{w}_{1}, \mathrm{w}_{2}, \ldots, \mathrm{w}_{\mathrm{n}}$ are the uncertainties associated with $\mathrm{x}_{1}, \mathrm{x}_{2}, \ldots, \mathrm{x}_{\mathrm{n}}$

Table 3

The experimental results and total uncertainties of the measured parameters

\begin{tabular}{lcc}
\hline Item & Average Value & Total uncertainty (\%) \\
\hline HTF temperature at HGHE inlet ( $\left.T_{\mathrm{wa}, \mathrm{i}}\right)$ & $21^{\circ} \mathrm{C}$ & \pm 1.38 \\
HTF temperature at HGHE outlet (Twa, $)$ & $70^{\circ} \mathrm{C}$ & \pm 1.38 \\
Ambient room temperature (Troom) & $16^{\circ} \mathrm{C}$ & \pm 1.38 \\
Insulation temperature on the outside of HGHE (Containers) & $20^{\circ} \mathrm{C}$ & \pm 1.38 \\
Soil temperature at top layer (layer 1) of HGHE (Tlayer1) & $65^{\circ} \mathrm{C}$ & \pm 1.38 \\
Soil temperature at top middle layer (layer 2) of HGHE (Tlayer2) & $70^{\circ} \mathrm{C}$ & \pm 1.38 \\
Soil temperature at bottom middle layer (layer 3) of HGHE (Tlayer 3$)$ & $68^{\circ} \mathrm{C}$ & \pm 1.38 \\
Soil temperature at bottom layer (layer 4) of HGHE (Tlayer4) & $62^{\circ} \mathrm{C}$ & \pm 1.38 \\
Mass flowrate of HTF & $0.0016-0.01 \mathrm{~L} / \mathrm{s}$ & \pm 2.89 \\
Electric current through system (1 of 3) & $0.55 \mathrm{~A}$ & \pm 3.00 \\
Voltage in heating cable (1 of 3) & $250 \mathrm{~V}$ & \pm 3.00 \\
Power input to heating cable & $240 \mathrm{~W}$ & \pm 3.10 \\
\hline
\end{tabular}

\section{Thermodynamic analysis}

This section focuses on using the laws of thermodynamics to assess the efficiency of the HGHEs. A list of the notations used in this section is given at the end of the paper. The assumptions made in the analysis presented in this study are:

- A closed system is in operation

- The heat transfer is steady state

- There is a steady flow in operation and assumes processes at constant pressure

- The HTF pressure drops in the pipes connecting the components are ignored, since lengths are short

- The heat is generated uniformly in the resistance electric heating cable

- Constant thermal-physical properties are used for materials (from Table 1 and 2)

\subsection{Heating requirement}

Calculating the total heat loss from the rectangular test room (with a floor plan $15 \mathrm{~m}^{2}$ ) is the first step in determining the heating load requirement before selecting the system components. The construction properties of the test room are given in Table 4 . The heating system capacity is sized to meet the needs of the test room under the coldest day of the winter season (outside temperature of $-6^{\circ} \mathrm{C}$ ) in Nottingham, UK. The ambient room temperature was recorded to be $15^{\circ} \mathrm{C}$ on that day. The total required heating load $\left(Q_{t h l}\right)$ of the room was found to be $0.97 \mathrm{~kW}$, approximately $1 \mathrm{~kW}$. 
Table 4

The construction properties of the test room

\begin{tabular}{llc}
\hline Construction & Properties & Value \\
\hline Window area & Glass, $\mathrm{U}=2.8 \mathrm{~W} / \mathrm{m}^{2 \circ} \mathrm{C}$ & $2 \mathrm{~m}^{2}$ \\
Wall area & Brick, $\mathrm{U}=0.32 \mathrm{~W} / \mathrm{m}^{2 \circ} \mathrm{C}$ & $39 \mathrm{~m}^{2}$ \\
Floor area & Concrete, $\mathrm{U}=0.7 \mathrm{~W} / \mathrm{m}^{2 \circ} \mathrm{C}$ & $15 \mathrm{~m}^{2}$ \\
Ceiling area & Concrete, $\mathrm{U}=0.8 \mathrm{~W} / \mathrm{m}^{2 \circ} \mathrm{C}$ & $15 \mathrm{~m}^{2}$ \\
Ventilation & $\mathrm{N}=1$ Air change $/ \mathrm{hr} ;$ Air Spht $=0.34$ & - \\
Dimensions of the room $(\mathrm{V})$ & $5.0 \mathrm{~mL}$ x 3.0mW x 3.0mH & $45 \mathrm{~m}^{3}$ \\
\hline
\end{tabular}

\subsection{Energy balance}

Based on the first law of thermodynamics, the rate of net energy transfer into the HGHE must equal the rate of energy transfer out by heat from the system as illustrated in equation 2.

$$
E_{\text {in }}=E_{\text {out }}
$$

Where: $E_{\text {in }}$ is the rate of net energy transfer into the HGHE $(\mathrm{kW})$ and $\mathrm{E}_{\text {out }}$ is the rate of net energy extracted from the HGHE $(\mathrm{kW})$

The energy required $\left(Q_{r e q}\right)$ to raise the temperature of the soil in the HGHEs from an initial starting temperature of $20^{\circ} \mathrm{C}$ to $65^{\circ} \mathrm{C}$ was calculated to be $14400 \mathrm{~kJ}$ using equation 3. From experimental testing, the actual energy inputted into the system $\left(Q_{i n}\right)$ was calculated using equation 4 . Over a heating period of 48 hours, the rate at which electrical energy dissipated from the three heating cables $(\dot{G})$ was $240 \mathrm{~W}$ as measured from an energy meter. Therefore, the HGHEs was charged with an energy $Q_{i n}$ of $41472 \mathrm{~kJ}$ (excluding heat losses from the system). The steady rate of heat loss $\left(Q_{\text {loss }}\right)$ through the insulation layer during the charging period (48 hours) was pre-calculated to be $0.075 \mathrm{~kW}$ or $12925 \mathrm{~kJ}$ using equation 5.
$Q_{\text {req }}=m_{\text {soil }} \cdot C_{p \text {,soil }} \cdot \Delta T_{\text {soil }}$
(eq. 3)
$Q_{\text {in }}=(\dot{G} . \Delta t)-Q_{\text {loss }}$
$Q_{\text {loss }}=\left[k_{\text {ins }} \cdot A_{\text {ins }} \cdot\left(\Delta T_{\text {ins }} / L_{\text {ins }}\right)\right] . \Delta t$

Where: $Q_{\text {req }}$ is the energy required to raise the temperature of the soil mass in the HGHEs $(\mathrm{kW})$; $\mathrm{m}_{\text {soil }}$ is the mass of soil in HGHEs $(\mathrm{kg}) ; \mathrm{C}_{\mathrm{p} \text {,soil }}$ is the specific heat of soil $(\mathrm{J} / \mathrm{kgK}) ; \Delta \mathrm{T}_{\text {soil }}$ is the temperature difference in soil $\left({ }^{\circ} \mathrm{C}\right)$; $\mathrm{Q}_{\text {in }}$ is the actual energy inputted into the HGHEs ( $\mathrm{kJ}$ or $\mathrm{kW}) ; \dot{\mathrm{G}}$ is the rate at which electrical energy is dissipated from the heating cable (W); $\Delta \mathrm{t}$ is the required time (s); Qloss is the steady rate of heat loss through the HGHEs (kJ or kW); $\mathrm{k}_{\text {ins }}$ is the thermal conductivity of the insulation XEPS $(\mathrm{w} / \mathrm{mK}) ; \mathrm{A}_{\text {ins }}$ is the area of insulation $(\mathrm{m} 2) ; \Delta \mathrm{T}_{\text {ins }}$ is the temperature difference insulation $\left({ }^{\circ} \mathrm{C}\right)$; $\mathrm{L}_{\text {ins }}$ is the length of insulation (m)

The quantity of heat extracted $\left(Q_{o u t}\right)$ from the HGHEs was calculated using equation 6, which considers the variation in HTF temperature and the quantity of HTF running through the pipe. Several mass flowrates were investigated experimentally, however, for calculation purposes only the lowest flowrate (LF) of $0.0016 \mathrm{~kg} / \mathrm{s}$ or $0.1 \mathrm{~L} / \mathrm{min}$ and highest flowrate (HF) of $0.01 \mathrm{~kg} / \mathrm{s}$ or $0.6 \mathrm{~L} / \mathrm{min}$ were considered. The $Q_{\text {out }}$ ranged between $32369 \mathrm{~kJ}(\mathrm{LF})$ and $13550 \mathrm{~kJ}$ (HF) for the sand (LB) filled HGHEs and between 24088kJ (LF) and 6775kJ (HF) for the gravel (GR) filled HGHEs. Considering the time taken to extract the heated HTF for each flowrate case, the total heat extracted for both the LB and GR filled HGHEs was calculated to be $0.21 \mathrm{~kW}(\mathrm{LF})$ and $1.25 \mathrm{~kW}$ (HF). This means that the heat exchange rate per pipe length is $14 \mathrm{~W} / \mathrm{m}$ and $83 \mathrm{~W} / \mathrm{m}$ for $\mathrm{LF}$ and $\mathrm{HF}$ respectively.

$Q_{o u t}=\dot{m}_{w a} \cdot C_{p, w a} \cdot\left(T_{w a, o}-T_{w a, i}\right)$

Where: Qout is the quantity of heat extracted from the HGHEs ( $\mathrm{kJ}$ or $\mathrm{kW}$ ); $\dot{\mathrm{m}}_{\mathrm{wa}}$ is the mass flowrate of the HTF (water) $(\mathrm{kg} / \mathrm{s})$; $\mathrm{C}_{\mathrm{p} \text {,wa }}$ is the specific heat of the HTF (water) $(\mathrm{J} / \mathrm{kgK}) ; \mathrm{T}_{\mathrm{wa}, \mathrm{o}}$ is the outlet average HTF temperature from HGHE ( $\left.{ }^{\circ} \mathrm{C}\right)$; $\mathrm{T}_{\text {wa, i }}$ is the inlet average HTF temperature from HGHE $\left({ }^{\circ} \mathrm{C}\right)$ 


\subsection{Energy efficiency}

The collection efficiency $(\eta)$ was calculated using equation 7 for both sand (LB) filled HGHEs and gravel (GR) filled HGHEs to compare output results. Equation 7 takes the ratio of heat extracted quantity from the HGHEs (Qout) to the heat stored in the HGHEs $\left(Q_{i n}\right)$. The maximum efficiency of the LB and GR filled HGHEs was calculated to be $78 \%$ and $58 \%$ respectively. It is noted that efficiencies were calculated based on soil temperatures $\left(20^{\circ} \mathrm{C}\right.$ to $\left.65^{\circ} \mathrm{C}\right)$ and heated $\mathrm{HTF}$ temperatures $\left(71^{\circ} \mathrm{C}\right.$ to $\left.35^{\circ} \mathrm{C}\right)$, which are not instantaneous values.

$\eta=Q_{\text {out }} / Q_{\text {in }}$

Where: $\eta$ is the efficiency of the HGHE system (\%)

The calculated energy values from the HGHEs are discussed in the results section.

\section{Results and discussion of experimental results}

\subsection{Soil thermal testing}

Preliminary results comparing the seven soil types, as sensible heat storage media's, are summarized as temperature vs. time graphs in Figure. 9 for sands and gravel (LB, BS, WS and GR) and Figure. 10 for clays (LB, MM, LI, GA). All seven soil filled containers were heated in the environmental chamber (EC) to reach a set optimum temperature to within $70^{\circ} \mathrm{C} \pm 2^{\circ} \mathrm{C}$ tolerance. The $\mathrm{T}_{\mathrm{EC}}$ curve shows the internal temperature of the environmental chamber (EC); the point at which the $\mathrm{T}_{\mathrm{EC}}$ curve heats up corresponds to the time the EC was switched on. Results show that it took 16 hours to heat the soil filled containers where LB achieved the highest peak temperature of $72^{\circ} \mathrm{C}$, followed by GR at $71^{\circ} \mathrm{C}$, then came BS, GA and LI at $70^{\circ} \mathrm{C}$ and finally WS at $69^{\circ} \mathrm{C}$. The containers were left for a further 8 hours (total of 24 hours) in the EC to ensure the soils were at a homogenous temperature before removing them.

In Figure's. 9 and 10, the point at which the $\mathrm{T}_{\mathrm{EC}}$ curve drops is the time the EC was switched off and the containers were removed for cooling. The soils retained their temperatures for the first 2 hours after removing them from the EC, then started to cool down. LB showed the best heat storage properties retaining heat for longer periods and cooling slower than other tested soils. As evident in Figure's 9 and 10, the LB and GR curve had a one to two hour gap between them and other soils. This is because the time it took for each soil to cool down to the same temperature of $35^{\circ} \mathrm{C}$ is different, for LB it took seven hours (hr 26 to hr 33), GR took six hours (hr 26 to hr 32), MM, LI, GA took five and a half hours and BS, WS took five hours (hr 26 to hr 31.5). Physical and thermal properties of soil materials (summarized in Table 1) were found to be important parameters in the performance of soils as sensible heat storage media's. Materials with a higher void space (LB and GR 40\%) and that are both poorly graded obtained better results compared to materials with lower void spaces, which is because the voids between the particles are filled with air, air acting as a thermal insulator, allowing the soil to retain heat for longer periods. Overall, it was concluded that the LB and GR soils had the best performance compared to other sands and clays tested for heat storage purposes. Both these soils (LB and GR) were tested as a backfill material in the HGHE to compare the performance of two filled systems.

\subsection{HGHEs testing}

Methods of storing and extracting heat from a HGHEs was investigated using two soil backfill materials (LB and GR) which were identified previously as better heat storage mediums. For simplicity, the LB filled HGHE is abbreviated to LB-HGHE and GR filled HGHE is abbreviated to GR-HGHE. Table 5 summarizes the experimental results obtained from the LB-HGHE and GR-HGHE under four output flowrates $(0.1,0.2,0.4$ and $0.6 \mathrm{~L} / \mathrm{min})$. Figure's. 11 to 14 show the results of temperature vs. time graphs for both HGHEs charging and discharging for two of the four output flowrates (Figure. 11: LB-HGHE 0.4L/min FR, Figure. 12: GR-HGHE 0.4L/min FR, Figure. 13: LB-HGHE 0.1L/min FR and Figure. 14: GR-HGHE 0.1L/min FR). 


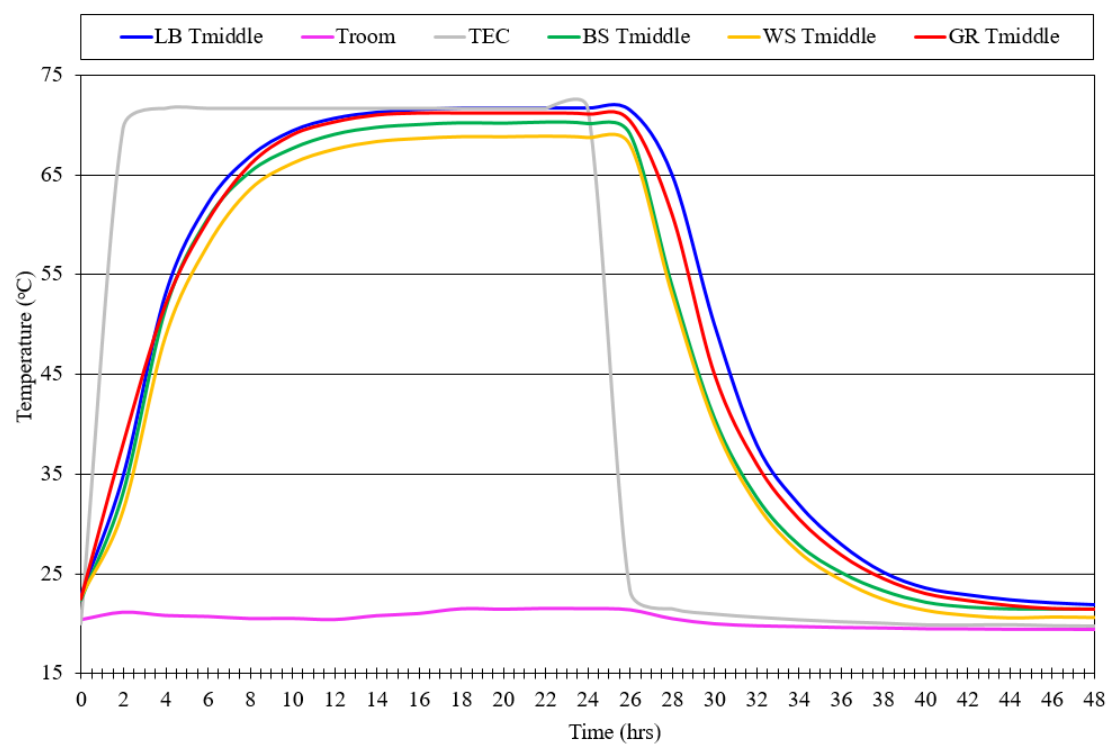

Figure. 9: Temperature vs. time results using sand and gravel (LB, BS, WS and GR) as heat storage media's

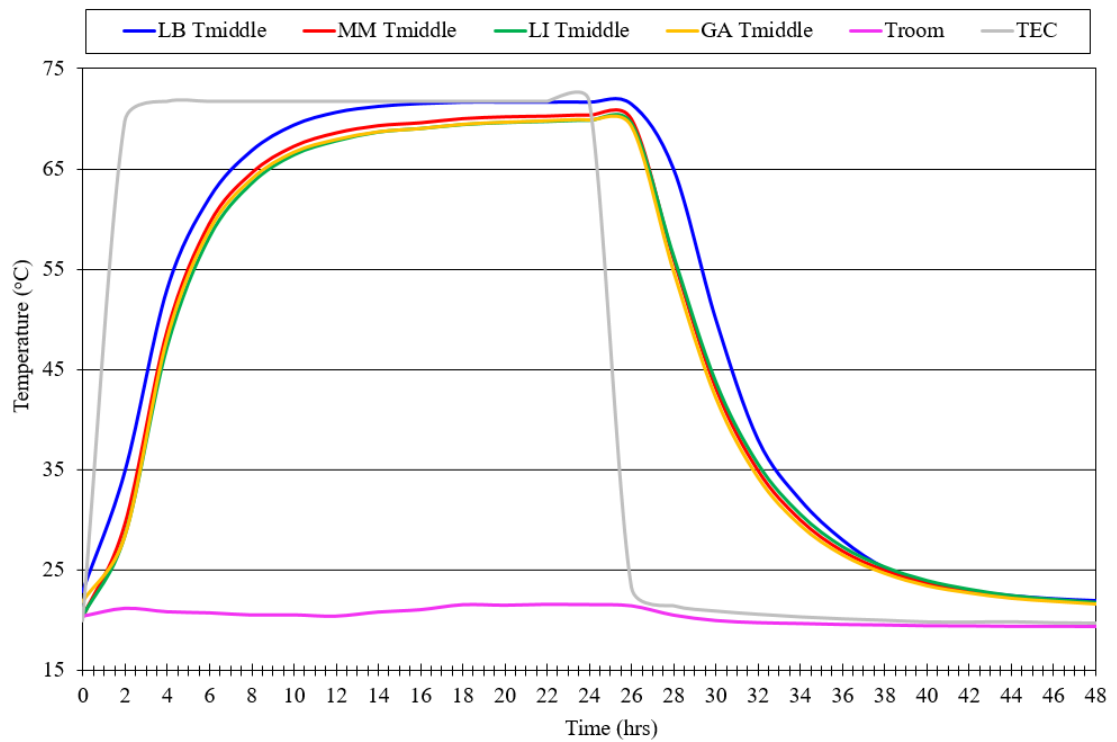

Figure. 10: Temperature vs. time results using sand (LB) and clays (MM, LI, GA) as heat storage media's

\subsubsection{HGHEs testing - Charging}

Thermocouples buried in the HGHEs showed that both LB-HGHEs and GR-HGHE started with temperatures of 15$22^{\circ} \mathrm{C}$ and during charging over the course 28 hours reached temperatures of $69-71^{\circ} \mathrm{C}$ using electric cables (see Table 5). The highest temperature values $\left(65-70^{\circ} \mathrm{C}\right)$ were recorded in layer 2 and 3 of the HGHEs for both LB-HGHEs and GR-HGHE as illustrated in Figure's. 11-14. Layers 2 and 3 were sandwiched between two layers of heating cable (above and below) and hence reached higher temperatures compared to Layers 1 and 4 . Additional tests were conducted to assess the effect on HGHEs temperatures with respect to longer charging periods, however, there was no significant effect on LB-HGHEs temperature. One of the objectives of this research was to reduce the temperature fluctuations in the HGHE due to external colder surroundings, a parameter that currently limits the use of HGHEs. This study, proposed insulating the HGHEs with a recycled XEPS material and installing thermocouples on the outer surface of the XEPS $\left(T_{\text {ins }}\right)$ to measure heat losses from the HGHEs during charging and discharging. $T_{\text {ins }}$ indicates that the temperature of the insulation starts at $14-19^{\circ} \mathrm{C}$ and increases to $23-25^{\circ} \mathrm{C}$ upon store charging for both $\mathrm{LB}$ and GR-HGHEs (Figure's 11-14) indicating a slight heat loss from the system. This means the XEPS insulation did successfully minimize temperature fluctuations heat loss to the surroundings, but, should still be improved in further studies. 
Table 5

Comparison of experimental results from LB-HGHEs and GR-HGHEs under different output flowrate

\begin{tabular}{|c|c|c|c|c|c|c|c|c|c|c|c|c|}
\hline & & & & Tem & rature & & & & & (ime & & $\begin{array}{l}\text { Quantity } \\
\text { (L) }\end{array}$ \\
\hline 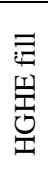 & $\begin{array}{c}\text { Water } \\
\text { Flow } \\
\text { (L/min) }\end{array}$ & $\begin{array}{l}\text { (A) } \\
\text { Soil } \\
\text { Start }\end{array}$ & $\begin{array}{l}\text { (B) } \\
\text { Soil } \\
\text { Max }\end{array}$ & $\begin{array}{l}\text { (C) } \\
\text { Ins } \\
\text { Start }\end{array}$ & $\begin{array}{l}\text { (D) } \\
\text { Ins } \\
\text { Max. }\end{array}$ & $\begin{array}{l}(\mathrm{E}) \\
\text { Inlet }\end{array}$ & $\begin{array}{c}\text { (F) } \\
\text { Outlet } \\
\text { Max. }\end{array}$ & $\begin{array}{l}(G) \\
\text { Steady } \\
\text { HGHE } \\
\text { Charge } \\
\text { Period }\end{array}$ & $\begin{array}{l}\text { (H) } \\
\text { Full } \\
\text { HGHE } \\
\text { Charge } \\
\text { Period }\end{array}$ & $\begin{array}{c}\text { (I) } \\
\text { Full } \\
\text { HGHE } \\
\text { Discharge } \\
\text { Period }\end{array}$ & $\begin{array}{c}(\mathrm{J}) \\
\text { Hot water } \\
\text { HGHE } \\
\text { Discharge } \\
\text { Period }\end{array}$ & $\begin{array}{c}\text { (K) } \\
\text { Hot } \\
\text { Water } \\
\text { Output }\end{array}$ \\
\hline 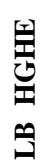 & $\begin{array}{c}0.1_{[F i g 13]} \\
0.2 \\
0.4_{[F i g 11]} \\
0.6\end{array}$ & $\begin{array}{l}21 \\
22 \\
22 \\
22\end{array}$ & $\begin{array}{l}70 \\
70 \\
70 \\
70\end{array}$ & $\begin{array}{l}19 \\
18 \\
17 \\
18\end{array}$ & $\begin{array}{l}25 \\
25 \\
24 \\
25\end{array}$ & $\begin{array}{l}21 \\
19 \\
19 \\
20\end{array}$ & $\begin{array}{l}69 \\
70 \\
70 \\
70\end{array}$ & $\begin{array}{l}28 \\
28 \\
28 \\
28\end{array}$ & $\begin{array}{l}48 \\
48 \\
48 \\
48\end{array}$ & $\begin{array}{l}74 \\
29 \\
27 \\
24\end{array}$ & $\begin{array}{c}43 \\
11 \\
5 \\
3\end{array}$ & $\begin{array}{l}258 \\
132 \\
120 \\
108\end{array}$ \\
\hline 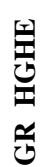 & $\begin{array}{c}0.1_{[F i g 14]} \\
0.2 \\
0.4_{[F i g 12]} \\
0.6\end{array}$ & $\begin{array}{l}19 \\
17 \\
21 \\
15\end{array}$ & $\begin{array}{l}71 \\
71 \\
71 \\
71\end{array}$ & $\begin{array}{l}17 \\
14 \\
16 \\
13\end{array}$ & $\begin{array}{l}24 \\
23 \\
25 \\
23\end{array}$ & $\begin{array}{l}19 \\
17 \\
20 \\
18\end{array}$ & $\begin{array}{l}71 \\
71 \\
71 \\
71\end{array}$ & $\begin{array}{l}28 \\
28 \\
28 \\
28\end{array}$ & $\begin{array}{l}48 \\
48 \\
48 \\
48\end{array}$ & $\begin{array}{l}57 \\
27 \\
20 \\
17\end{array}$ & $\begin{array}{c}32 \\
5 \\
3 \\
1.5\end{array}$ & $\begin{array}{c}192 \\
120 \\
108 \\
54\end{array}$ \\
\hline
\end{tabular}

Note: Table 5 was compiled from interpreting graph data from Figure's 11-14 and refers to lettered regions annotated in Figure. 11 as an example. The letters indicate the following: (A) Starting temperature of soil in HGHE prior to charging; (B) Maximum temperature of soil in HGHE after charging; (C) Starting temperature of insulation in HGHE prior to charging; (D) Maximum temperature of insulation in HGHE after charging; (E) Inlet temperature of HTF (water) entering HGHE when discharging ; (F) Maximum outlet temperature of HTF (water) extracted from HGHE when discharging; (G) Time for HGHE to reach steady temperatures (charging) ; $(\mathrm{H})$ Total charging time of HGHE, soil reaching maximum temperature of $70^{\circ} \mathrm{C}$; (I) Total discharging time of HGHE, HTF (water) cools down to $20^{\circ} \mathrm{C}$; (J) Hot water discharging time from HGHE, HTF (water) cools down to $35^{\circ} \mathrm{C}$; (K) Calculated output quantity of hot water extracted from HGHEs $\left(\mathrm{Max}-35^{\circ} \mathrm{C}\right)$

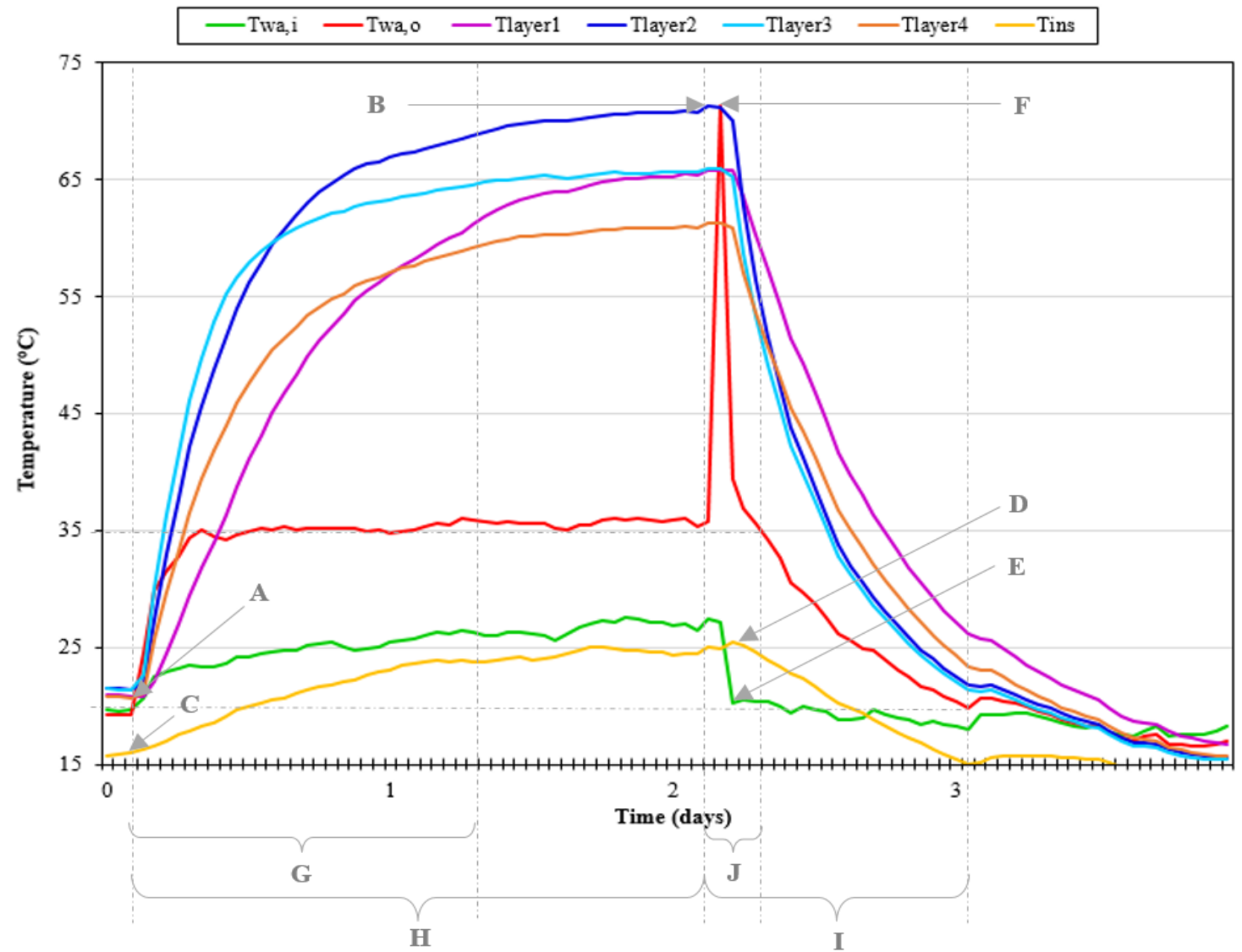

Figure. 11: Temperature vs. time results for sand (LB) filled HGHEs with an output flowrate of $0.4 \mathrm{~L} / \mathrm{min}$ 


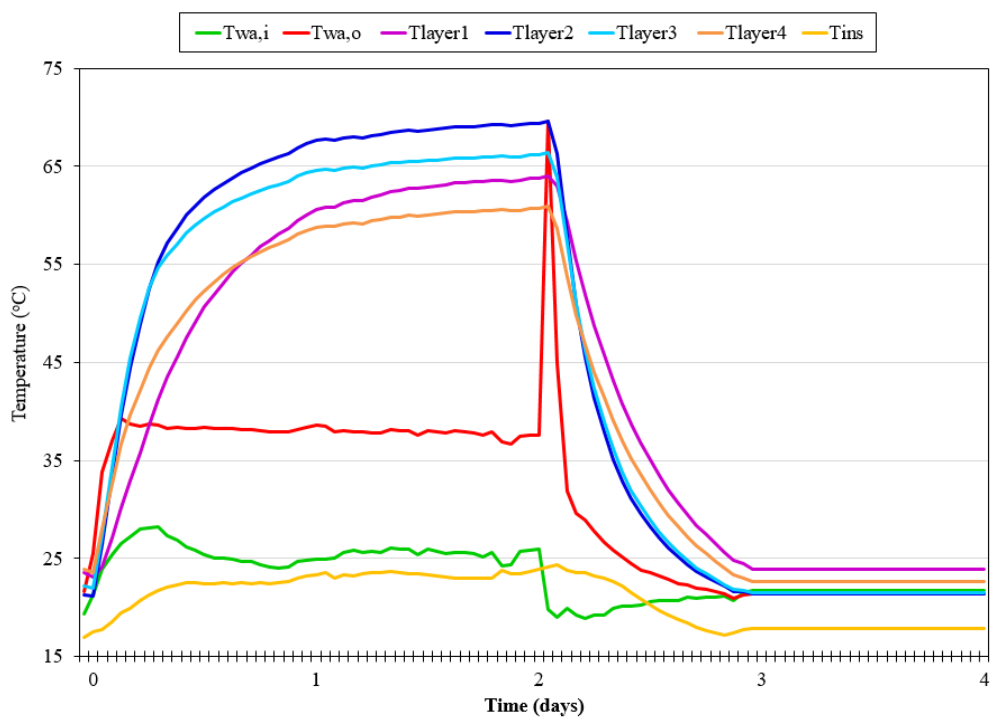

Figure. 12: Temperature vs. time results for gravel (GR) filled HGHEs with an output flowrate of $0.4 \mathrm{~L} / \mathrm{min}$

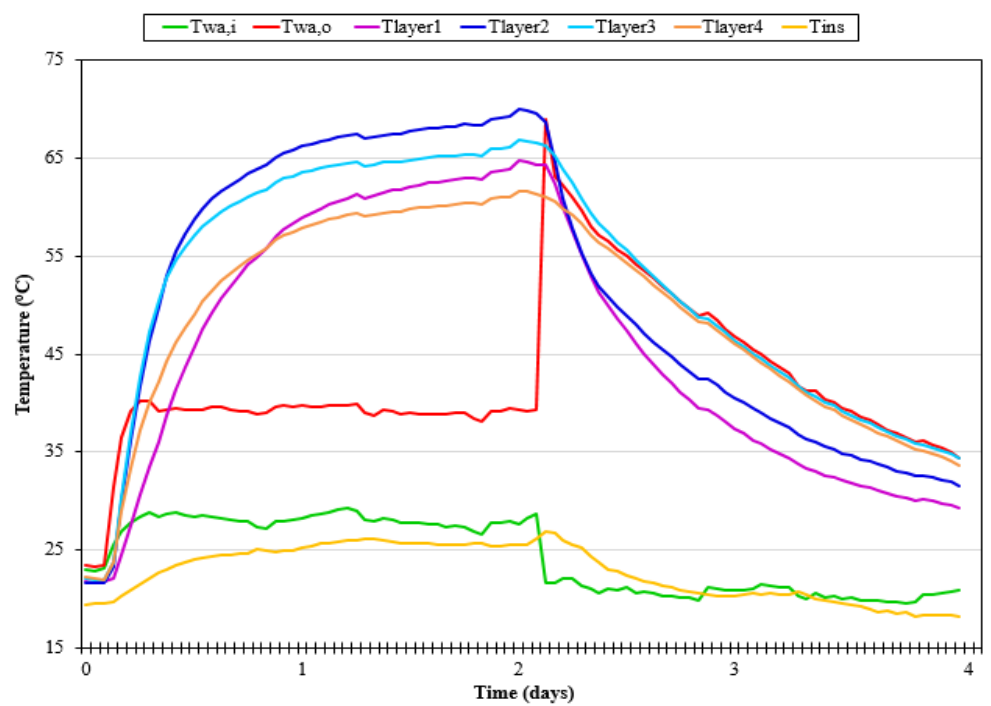

Figure. 13: Temperature vs. time results for sand (LB) filled HGHEs with an output flowrate of $0.1 \mathrm{~L} / \mathrm{min}$

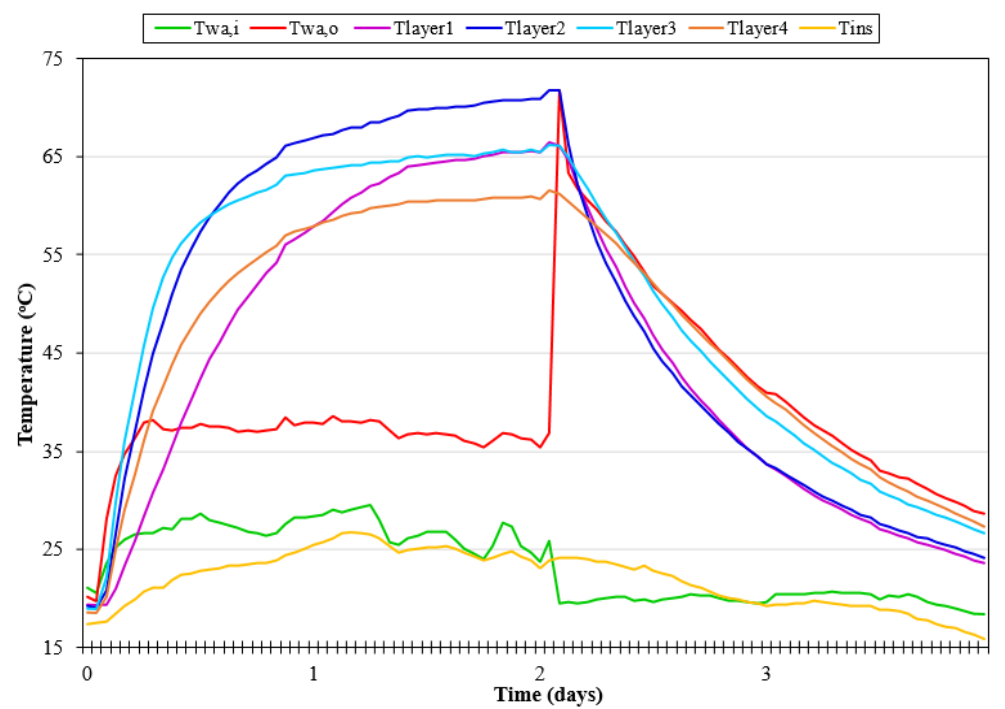

Figure. 14: Temperature vs. time results for gravel (GR) filled HGHEs with an output flowrate of $0.1 \mathrm{~L} / \mathrm{min}$ 


\subsubsection{Discharging sand filled HGHEs (LB-HGHEs)}

As illustrated in Figure's 11, 13 and Table 5, the HTF entered the LB-HGHE at temperatures ranging between 18$21^{\circ} \mathrm{C}\left(T_{w a, i}\right)$ for all tested flowrates. The maximum HTF output temperature $\left(T_{w a, o}\right)$ extracted from the system was $70^{\circ} \mathrm{C}$ and the total hot water $\left(\mathrm{T}>35^{\circ} \mathrm{C}\right)$ extracted using a $0.1 \mathrm{~L} / \mathrm{min}$ flowrate was found to be $258 \mathrm{~L}$ over the course of 43 hours (see Figure 13 \& Table 5). Results with a higher output flowrate of $0.6 \mathrm{~L} / \mathrm{min}$ showed the outlet temperature dropped from $70^{\circ} \mathrm{C}$ to $35^{\circ} \mathrm{C}$ within 3 hours, providing only $108 \mathrm{~L}$ of extracted hot water (see Table 5). When comparing these results for a 0.1 and $0.6 \mathrm{~L} / \mathrm{min}$ output flowrates from the LB-HGHE, it can be concluded that as the output flowrate increases, there is a reduction in the quantity (decrease of 58\%) and duration (decrease of 93\%) of extracted hot water for a $0.5 \mathrm{~L} / \mathrm{min}$ flowrate difference. The reason for this is because at lower flower rates there is sufficient time for the heat exchange to occur between the surrounding LB soil to the HTF in the GHE allowing it remain hot for longer periods, conversely, at higher output flowrates, there is a lack of heat exchange between the soil, GHE and HTF and hence the system is cooled down more rapidly. LB-HGHE output flowrate results for 0.2 and $0.4 \mathrm{~L} / \mathrm{min}$ from Table 5 confirm this result trend between 0.1 and $0.6 \mathrm{~L} / \mathrm{min}$. In addition, Figures. 11,13 shows that the output water temperature $\left(T_{w a, o}\right)$ is directly correlated with the temperature of the LB soil layers $\left(T_{\text {layer } 1}-\right.$ $T_{\text {layer } 4}$ ) in the storage, and that as the heat is extracted from the HGHEs through the HTF, the soil's temperature reduces until all the heat has been extracted from the system (i.e soil media reaches equilibrium with HTF).

\subsubsection{Discharging gravel filled HGHEs (GR-HGHEs)}

The results from GR-HGHE shows a similar trend to that obtained with LB-HGHE, however the performance of GR-HGHE was overall poorer compared to LB-HGHE. Considering the lowest output flowrate of $0.1 \mathrm{~L} / \mathrm{min}$ in GRHGHE, the HTF output temperature was roughly similar to that obtained for LB-HGHE at $71^{\circ} \mathrm{C}$, but the total heated water $\left(\mathrm{T}>35^{\circ} \mathrm{C}\right)$ extracted from the GR-HGHEs was found to be $192 \mathrm{~L}$ over 32 hours (see Figure 14 \& Table 5). This means that an additional 66L of hot water was extracted from the LB-HGHEs compared to GR-HGHE at a $0.1 \mathrm{~L} / \mathrm{min}$ flowrate (an increase of approximately 26\%). Results from GR-HGHE with a higher flowrate of $0.6 \mathrm{~L} / \mathrm{min}$ showed that only 54L of hot water was collected during 1.5 hours (see Table 5). Again a similar trend to LB-HGHE was observed for GR-HGHE, whereby when increasing the flowrate from 0.1 and $0.6 \mathrm{~L} / \mathrm{min}$, the hot water quantity decreased by $72 \%$ and the duration by $95 \%$. Results for GR-HGHE with a 0.2 and $0.4 \mathrm{~L} / \mathrm{min}$ output flowrate (see Table 5) further confirm the result trend between 0.1 and $0.6 \mathrm{~L} / \mathrm{min}$.

Finally, LB-HGHE produced approximately 50\% more hot water during a longer duration ( $50 \%$ increase) compared to GR-HGHE. This difference in result is perhaps due to the arrangement of soil particles within the HGHE. A good heat HGHE media must be able to exchange heat to and from the HTF in the copper pipe. LB sand particles are between 0.425 to $1.18 \mathrm{~mm}$ in size and are rounded in shape, with a density of $1562 \mathrm{~kg} / \mathrm{m}^{3}$ (see Table 1). The gradation of the sand means the particles can pack closely together and create a better particle contact surface with the GHE copper piping. Whereas, the GR gravel used in this study consisted of larger particles ranging between 2 and $10 \mathrm{~mm}$ in size with an overall lower density of $1451 \mathrm{~kg} / \mathrm{m}^{3}$ (see Table 1). Due to the larger size and angular nature of the GR particles compared to LB, it appears that the gravel particles did not pack closely together, creating poor and insufficient contact between adjacent particles and the GHE pipe, subsequently reducing the heat transfer occurring. This can explain why less hot water was extracted from GR-HGHEs.

A thermodynamic analysis of both LB-HGHE and GR-HGHE system's was conducted. The total heat stored ( $\left.Q_{\text {in }}\right)$ in the HGHEs was calculated to be $41472 \mathrm{~kJ}$ using material properties specified in Table 1 and 2 . The total heat extracted ( $\left.Q_{o u t}\right)$ from LB and GR-HGHEs was calculated using the quantity of heated water produced from the HGHEs, this was found to be between $0.21 \mathrm{~kW}$ with a lower flowrate of $0.0016 \mathrm{~kg} / \mathrm{s}$ and $1.25 \mathrm{~kW}$ with a higher flowrate of $0.01 \mathrm{~kg} / \mathrm{s}$. The total heating load requirement of the room was calculated to be $1 \mathrm{~kW}$, which means that irrespective of soil media, the HGHEs operating at higher flowrates can produce enough hot water to heat the room comfortably. The efficiency of the LB-HGHE is currently operating at 78\% compared to the GR-HGHE with a lower efficiency of $58 \%$. 
To show accuracy of the system developed in this study, the results were compared to that from comparable studies. A similar HGHE system developed by Kim et al. (2016) and filled with a typical Korean sand (Joomunjin) in a dry condition using sand had similar material properties to the LB sand used in this study, with respect to density, thermal conductivity and specific heat capacity. However, there are three variations in the system compared to this study , these are: (1) the volume of the system is $5 \mathrm{~m}^{3}$ (2) the system uses a spiral coil and (3) the average flow rate of the circulating water was 4-5.5 L/min. Kim et al. (2016) conducted thermal response tests (TRTs) on the HGHEs and found that the temperature of the circulating HTF (water) reached a near steady state after $20 \mathrm{~h}$ from the beginning of the TRT. This is comparable with the result obtained in this study. Kim et al. (2016) also found that the heat exchange rates of coil-type GHE were $255.3 \mathrm{~W}$ (or $14.45 \mathrm{~W} / \mathrm{m}$ ) and $260.2 \mathrm{~W}$ (or $10.64 \mathrm{~W} / \mathrm{m}$ ) for the slinky-type. These heat exchange rates are similar to that obtained in this study for both the sand and gravel filled systems. A similar three dimensional numerical analysis study simulating the thermal behavior of a horizontal spiral-coil-loop heat exchanger was developed by Go et al. (2016) and showed that when inlet fluid velocity is fast, the heat efficiency decreases due to thermal interference among the pipe. This trend is also evident from the efficiencies obtained in this study with low and high flowrates.

The daily mean household hot water consumption in the UK is $122 \pm 18$ litres/day and the mean heating time is $2.60 \pm 0.35$ hours/day (Energy Saving Trust 2008). Although the HGHEs produced in this study was designed on a small scale for experimental purposes only, the hot water quantity, temperature range and duration produced from the system were in line with LTDH guidelines and can be applied to some household heating applications. As discussed, the quantity of hot water produced from the system is distributed over a period of time (variable between hours and days depending on flowrate) and therefore, the system can be used for low required flowrates including underfloor heating applications purposes. In order to meet the standard temperatures for under-floor heating, the inlet temperature has to be $55^{\circ} \mathrm{C}$ with a return flow of $45^{\circ} \mathrm{C}$ were both satisfied by the results. Standard under-floor heating systems also require a heated water flowrate in the region of 1.55L/min (Antizar-Ladislao et al. 2010). Although the other factors were satisfied, due to the small size of the system, the maximum output flowrate of the HGHE was only $0.6 \mathrm{~L} / \mathrm{min}$. The system produced in this study will also struggle with a high flowrate demanding operation; for example; running a hot bath, whereby instantaneous delivery of hot water within a short period of time is required.

\section{Conclusions}

This paper can be summarized in two parts. The first part of this paper presents a comparative study of heat transfer in seven soils to be utilized as sensible heat storage media's. In the second part, an experimental solar simulated HGHEs was installed and tested to investigate the thermal performance of the system using two soils as backfill material with four varying output flowrates. The HGHE was designed for low temperature and low flowrate working conditions. The results obtained from this study are useful to system designers in the selection of an appropriate material for HGHE requirements. The following conclusions and recommendations can be drawn from the results of this study:

1. LB sand and GR gravel soils showed the best heat storage performance properties, retaining heat for longer periods and cooling slower compared to other tested sands and clays (BS, WS, MM, LI, GA). Thermal-physical properties were found to be important parameters in the performance of these soils as heat storage materials.

2. An extensive experimental testing program was conducted on the HGHEs, which operated without problems as a daily heat storage unit. The results indicate that the system can be heated using electrical cables simulating excess electricity produced from PV. Thermocouples buried in the system show that both LB and GR filled systems charged over the course of 28 hours.

3. The stored heat can then be extracted from the HGHEs as hot water production for temperatures of $35-70^{\circ} \mathrm{C}$, in line with LTDH standards to meet a test room heating load of $1 \mathrm{~kW}$. The present paper contains side by side performance comparisons using LB and GR soil materials as HGHE fill with four output flowrates (0.1, 0.2, 0.4 and $0.6 \mathrm{~L} / \mathrm{min}$ ). The discharge time of the HGHE differed with respect to the flowrate and material fill. LB-HGHE 
produced approximately 50\% more hot water during a 50\% longer duration compared to GR-HGHE. This difference is possibly due to the arrangement of soil particles within the HGHE. From a thermodynamic analysis, the efficiency of the HGHE system is $78 \%$ and $58 \%$ respectively for the LB-HGHE and GR-HGHE. The results obtained from the experimental HGHEs were in reasonable agreement to that from similar studies in literature. The system produced in this study can be applied to meet low temperature and low flow space heating requirements, for example, underfloor space heating applications.

4. The HGHE should be insulated well to avoid heat loss to the ambient surrounding temperature. The XEPS used to insulate the system in this study worked well to retain the heat within the system and needs to be further developed.

5. In a further study, more experimental data are collected using other storage materials. The performance of the HGHE system should be examined over the long term to optimize the storage parameters and improve the overall collection efficiency of the designed HGHEs. Recommendation includes adding a GSHP to the system.

\section{Acknowledgments}

The authors gratefully acknowledge the financial support from the REMOURBAN project supported by the EU Horizon 2020 research and innovation programme under grant agreement No 646511. The sponsor had no involvement in the design or delivery of this paper.

\section{Disclosure statement}

No potential conflict of interest was reported by the authors.

\begin{tabular}{ll}
\multicolumn{2}{l}{ Abbreviations } \\
GHEs & ground heat exchanger system \\
HGHE & horizontal ground heat exchanger \\
GSHP & ground source heat pump \\
MDF & modified density fibreboard \\
XEPS & extruded polystyrene foam \\
HTF & heat transfer fluid \\
PSD & particle size distribution \\
FB & from bottom of store (baseline) \\
GR & gravel \\
LB & leighton buzzard sand \\
WS & washed sand \\
BS & building sand \\
MM & mercia mudstone clay \\
GA & gault clay \\
LI & lias clay \\
LF & low mass flowrate \\
HF & high mass flowrate \\
EC & environmental chamber \\
UK & united kingdom
\end{tabular}




\section{Nomenclature}

$\rho \quad$ density of material $\left(\mathrm{kg} / \mathrm{m}^{3}\right)$

$\rho_{\mathrm{p}} \quad$ particle density of soil $\left(\left(\mathrm{kg} / \mathrm{m}^{3}\right)\right.$

$\rho_{\mathrm{b}} \quad$ bulk density of soil $\left(\mathrm{kg} / \mathrm{m}^{3}\right)$

$\mathrm{C}_{\mathrm{p}} \quad$ specific heat capacity of material ( $\left.\mathrm{J} / \mathrm{kg} \mathrm{K}\right)$

$\mathrm{n} \quad$ porosity of soil (\%)

$\mathrm{K} \quad$ thermal conductivity of material $(\mathrm{W} / \mathrm{mK})$

$\mathrm{R}_{\lambda} \quad$ thermal resistivity of material $\left(\mathrm{m}^{\circ} \mathrm{C} / \mathrm{W}\right)$

$\mathrm{WR}_{\mathrm{R}} \quad$ uncertainty

$\mathrm{Wn}_{\mathrm{n}} \quad$ independent variables

$\mathrm{T}_{\mathrm{EC}} \quad$ temperature inside environmental chamber $\left({ }^{\circ} \mathrm{C}\right)$

$\mathrm{T}_{\text {Right }} \quad$ right of the tin temperature reading $\left(11.5 \mathrm{~cm}\right.$ from center of $10 \mathrm{~L}$ tin) $\left({ }^{\circ} \mathrm{C}\right)$

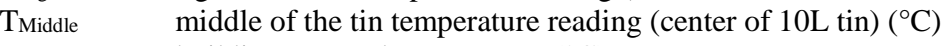

$\mathrm{T}_{\text {outside }} \quad$ building external temperature $\left({ }^{\circ} \mathrm{C}\right)$

$\mathrm{T}_{\text {room }} \quad$ ambient room temperature $\left({ }^{\circ} \mathrm{C}\right)$

$\emptyset_{\text {ext }} \quad$ external copper pipe diameter (mm)

$\emptyset_{\text {int }} \quad$ internal copper pipe diameter $(\mathrm{mm})$

$\mathrm{P} \quad$ power input to heating cable (W)

$\mathrm{V} \quad$ voltage input to heating cable (V)

I ampere input to heating cable (A)

$\mathrm{U} \quad$ heat transfer coefficient (U value) of material $\left(\mathrm{W} / \mathrm{m}^{2 \circ} \mathrm{C}\right)$

$\mathrm{N} \quad$ number of air change per hour (air rate/hr)

$\mathrm{V} \quad$ internal volume of room $\left(\mathrm{m}^{3}\right)$

Ein the rate of net energy transfer into the HGHE (kW)

E out the rate of net energy extracted from the HGHE $(\mathrm{kW})$

Qthl total heating load requirement of room/total heat loss from room $(\mathrm{kW})$

Qreq the energy required to raise the temperature of the soil mass in the HGHEs $(\mathrm{kW})$

$Q_{\text {in }} \quad$ the actual energy inputted into the HGHEs ( $\mathrm{kJ}$ or $\left.\mathrm{kW}\right)$

Qloss the steady rate of heat loss through the HGHEs ( $\mathrm{kJ}$ or $\mathrm{kW})$

Qout the quantity of heat extracted from the HGHEs ( $\mathrm{kJ}$ or $\mathrm{kW})$

$\eta \quad$ efficiency of the HGHE system (\%)

$\dot{\mathrm{G}} \quad$ the rate at which electrical energy is dissipated from the heating cable (W)

$\mathrm{m}_{\text {soil }} \quad$ mass of soil in HGHEs $(\mathrm{kg})$

$\dot{\mathrm{m}}_{\text {wa }} \quad$ mass flowrate of the HTF (water) $(\mathrm{kg} / \mathrm{s})$

$\Delta \mathrm{T} \quad$ temperature difference $\left({ }^{\circ} \mathrm{C}\right)$

$\Delta \mathrm{t} \quad$ required time (s)

Ains $\quad$ area of insulation through which heat is lost from the HGHEs $\left(\mathrm{m}^{2}\right)$

Lins thickness of insulation through which heat is lost from the HGHEs (m)

$\mathrm{T}_{\mathrm{wa}, \mathrm{o}} \quad$ outlet average $\mathrm{HTF}$ temperature from $\mathrm{HGHE}\left({ }^{\circ} \mathrm{C}\right)$

$\mathrm{T}_{\mathrm{wa}, \mathrm{i}} \quad$ inlet average $\mathrm{HTF}$ temperature from $\mathrm{HGHE}\left({ }^{\circ} \mathrm{C}\right)$

Containers average insulation temperature on the outside of soil layer in HGHEs $\left({ }^{\circ} \mathrm{C}\right)$

Tlayer1 average soil temperature at top layer (layer 1 ) of HGHE $\left({ }^{\circ} \mathrm{C}\right)$

Tlayer2 average soil temperature at top middle layer (layer 2$)$ of HGHE $\left({ }^{\circ} \mathrm{C}\right)$

$\mathrm{T}_{\text {layer3 }} \quad$ average soil temperature at bottom middle layer (layer 3$)$ of $\mathrm{HGHE}\left({ }^{\circ} \mathrm{C}\right)$

Tlayer4 average soil temperature at bottom layer (layer 4 ) of HGHE $\left({ }^{\circ} \mathrm{C}\right.$ ) 


\section{References}

Antizar-Ladislao, B., Irvine, G. \& Lamont, E.R., 2010. Energy from waste: Reuse of compost heat as a source of renewable energy. International Journal of Chemical Engineering, 2010.

Badescu, V., 2002. First and second law analysis of a solar assisted heat pump based heating system. Energy Conversion and Management, 43, pp.2539-2552.

Ball, D.A., Fischer, R.D. \& Hodgett, D.L., 1983. Design methods for ground-source heat pumps. ASHRAE Trans., 89, pp.416-440.

Bertermann, D., Klug, H. \& Morper-busch, L., 2015. A pan-European planning basis for estimating the very shallow geothermal energy potentials. Renewable Energy, 75, pp.335-347. Available at: http://dx.doi.org/10.1016/j.renene.2014.09.033.

Bose, J.E. \& Smith, M.D., 1992. Performance of new ground heat exchangers configurations for heat pump. Journal of Solar Engineering, (1), pp.385-393.

Congedo, P.M., Colangelo, G. \& Starace, G., 2012. CFD simulations of horizontal ground heat exchangers : A comparison among different con fi gurations. Applied Thermal Engineering, 33-34, pp.24-32. Available at: http://dx.doi.org/10.1016/j.applthermaleng.2011.09.005.

Cui, P., Yang, H. \& Fang, Z., 2008. Numerical analysis and experimental validation of heat transfer in ground heat exchangers in alternative operation modes. Energy and Buildings, 40, pp.1060-1066.

Energy Saving Trust, 2008. Measurement of Domestic Hot Water Consumption in Dwellings. Energy Savings Trust. Available at: http://scholar.google.com/scholar?hl=en\&btnG=Search\&q=intitle:Measurement+of+Domestic+Hot+Water+Consumption+in+Dwelli ngs\#0.

Esen, H., Esen, M. \& Ozsolak, O., 2016. Modelling and experimental performance analysis of solar-assisted ground source heat pump system. Experimental \& Theoretical Artificial Intelligence, (September 2015).

Esen, H., Inalli, M. \& Esen, M., 2007. Numerical and experimental analysis of a horizontal ground-coupled heat pump system. Building and Environment, 42, pp.1126-1134.

Esen, H., Inalli, M. \& Esen, Y., 2015. Temperature distributions in boreholes of a vertical ground-coupled heat pump system. Renewable Energy, 34(12), pp.2672-2679. Available at: http://dx.doi.org/10.1016/j.renene.2009.04.032.

Esen, H. \& Turgut, E., 2015. Optimization of operating parameters of a ground coupled heat pump system by Taguchi Method. Energy \& Buildings, 107(November), pp.329-334. Available at: http://dx.doi.org/10.1016/j.enbuild.2015.08.042.

Esen, M. \& Yuksel, T., 2013. Experimental evaluation of using various renewable energy sources for heating a greenhouse. Energy \& Buildings, 65, pp.340-351. Available at: http://dx.doi.org/10.1016/j.enbuild.2013.06.018.

Florides, G. \& Kalogirou, S., 2007. Ground heat exchangers-A review of systems, models and applications. Renewable Energy, 32(15), pp.2461-2478.

Gan, G., Riffat, S.B. \& Chong, C.S.A., 2007. A novel rainwater - ground source heat pump - Measurement and simulation. Applied Thermal Engineering, 27, pp.430-441.

Garg, H.., 1985. Solar Thermal Energy Storage First., Dordrecht, Holland: D. Reidel Publishing Company.

Gonzalez, R.G. et al., 2012. Interactions between the physical soil environment and a horizontal ground coupled heat pump , for a domestic site in the UK. Renewable Energy, 44, pp.141-153. Available at: http://dx.doi.org/10.1016/j.renene.2012.01.080.

Holman, J.P., 1994. Experimental Methods for Engineers sixth ed., Singapore: McGraw-Hill. Huang, B.J. \& Chyng, J.P., 2001. PERFORMANCE CHARACTERISTICS OF INTEGRAL TYPE SOLAR- ASSISTED HEAT PUMP. Solar Energy, 71(6), pp.403-414.

Inalli, M. \& Esen, H., 2005. Seasonal cooling performance of a ground-coupled heat pump system in a hot and arid climate. Renewable Energy, 30, pp.1411-1424. 
İnall1, M. \& Esen, H., 2004. Experimental thermal performance evaluation of a horizontal ground-source heat Engineering, Applied Thermalpump system. Applied Thermal Engineering, 2219-2232.

Kavanaugh, S.P., 2000. Field tests for ground thermal properties -- Methods and impact on ground-source heat pump design. In ASHRAE Trans. pp. 851-855.

Kaygusuz, K., 2000. Experimental and theoretical investigation of a solar heating system with heat pump. Renewable Energy, 21, pp.79-102.

Kim, M. et al., 2016. Geothermics Thermal performance evaluation and parametric study of a horizontal ground heat exchanger. Geothermics, 60, pp.134-143. Available at: http://dx.doi.org/10.1016/j.geothermics.2015.12.009.

Koyun, A., Demir, H. \& Torun, Z., 2009. Experimental study of heat transfer of buried fi nned pipe for ground source heat pump applications 认. International Communications in Heat and Mass Transfer, 36(7), pp.739-743. Available at: http://dx.doi.org/10.1016/j.icheatmasstransfer.2009.03.022.

Kupiec, K., Larwa, B. \& Gwadera, M., 2015. Heat transfer in horizontal ground heat exchangers. Applied Thermal Engineering, 75, pp.270-276. Available at: http://www.sciencedirect.com/science/article/pii/S1359431114008746.

Lee, J., Kim, T. \& Leigh, S., 2015. Applications of building-integrated coil-type ground-coupled heat exchangers — Comparison of performances of vertical and horizontal installations. Energy \& Buildings, 93, pp.99-109. Available at: http://dx.doi.org/10.1016/j.enbuild.2015.02.020.

Lund, J.W., Freeston, D.H. \& Boyd, T.L., 2005. Direct application of geothermal energy : 2005 Worldwide review ๕. Geothermics, 34, pp.691-727.

Luo, J. et al., 2016. A review of ground investigations for ground source heat pump ( GSHP ) systems. Energy \& Buildings, 117, pp.160-175. Available at: http://dx.doi.org/10.1016/j.enbuild.2016.02.038.

Metz, P.D., 1983. Ground Coupled Heat Pump System Experimental Results.

Naylor, S., Ellett, K.M. \& Gustin, A.R., 2015. Spatiotemporal variability of ground thermal properties in glacial sediments and implications for horizontal ground heat exchanger design. Renewable Energy, 81, pp.21-30. Available at: http://dx.doi.org/10.1016/j.renene.2015.03.006.

Ozgener, O. \& Hepbasli, A., 2005a. Experimental performance analysis of a solar assisted ground-source heat pump greenhouse heating system. Energy and Buildings, 37, pp.101-103.

Ozgener, O. \& Hepbasli, A., 2007. Modeling and performance evaluation of ground source ( geothermal ) heat pump systems. Energy and Buildings, 39, pp.66-75.

Ozgener, O. \& Hepbasli, A., 2005b. Performance analysis of a solar-assisted ground-source heat pump system for greenhouse heating : an experimental study. Building and Environment, 40, pp.1040-1050.

Ozgener, O., Hepbasli, A. \& Ozgener, L., 2007. A parametric study on the exergoeconomic assessment of a vertical ground-coupled ( geothermal ) heat pump system. Building and Environment, 42, pp.1503-1509.

Reyes, E.T., Nunez, M.P. \& Cervantes, D.G., 1998. EXERGY ANALYSIS AND OPTIMIZATION OF A SOLAR-. Energy, 23(4), pp.337-344.

Sarbu, I. \& Sebarchievici, C., 2015. General review of ground-source heat pump systems for heating and cooling of buildings. Energy \& Buildings, 70(February 2014), pp.441-454. Available at: http://dx.doi.org/10.1016/j.enbuild.2013.11.068.

Verma, V. \& Murugesan, K., 2014. Optimization of solar assisted ground source heat pump system for space heating application by Taguchi method and utility concept. Energy \& Buildings, 82, pp.296-309. Available at: http://dx.doi.org/10.1016/j.enbuild.2014.07.029. 
Wong B., Snijders A., M.L., 2006. Recent Inter-seasonal Underground Thermal Energy Storage Applications in Canada. IEEE EIC Climate Change Technology, pp.1-7.

Wu, S., 2010. Materials for Energy Efficiency and Thermal Comfort in Buildings. Materials for Energy Efficiency and Thermal Comfort in Buildings, pp.101-126. Available at: http://www.sciencedirect.com/science/article/pii/B9781845695262500049.

Wu, Y. et al., 2010. Experimental measurement and numerical simulation of horizontal-coupled Slinky Ground Source Heat Exchangers PhD dissertation View project. Applied Thermal Engineering, 30(16), pp.2574-2583. Available at: http://dx.doi.org/10.1016/j.applthermaleng.2010.07.008.

Wu, Y. et al., 2011. Prediction of the thermal performance of horizontal-coupled ground-source heat exchangers. International Journal of Low Carbon Technologies, (July), pp.261-269.

Yamankaradeniz, R. \& Horuz, I., 1998. The theoretical and experimental investigation of the characteristics of solar-assisted heat pump for clear days. Heat Mass Transfer, 25(6), pp.885-898.

Yang, W., 2013. Experimental performance analysis of a direct-expansion ground source heat pump in Xiangtan , China. Energy, 59, pp.334-339. Available at: http://dx.doi.org/10.1016/j.energy.2013.07.036.

Yong, L. \& Sumathy, K., 2004. Modeling and simulation of a solar powered two bed adsorption air conditioning system. Energy Conversion And Management, 45, pp.2761-2775. 